\title{
A review of the (Revised) Universal Soil Loss Equation ((R)USLE): with a view to increasing its global applicability and improving soil loss estimates
}

\author{
Rubianca Benavidez, Bethanna Jackson, Deborah Maxwell, and Kevin Norton \\ School of Geography, Environment, and Earth Sciences, Victoria University of Wellington, Wellington, 6012, New Zealand \\ Correspondence: Rubianca Benavidez (rubianca.benavidez@vuw.ac.nz)
}

Received: 12 February 2018 - Discussion started: 23 February 2018

Revised: 28 October 2018 - Accepted: 30 October 2018 - Published: 27 November 2018

\begin{abstract}
Soil erosion is a major problem around the world because of its effects on soil productivity, nutrient loss, siltation in water bodies, and degradation of water quality. By understanding the driving forces behind soil erosion, we can more easily identify erosion-prone areas within a landscape to address the problem strategically. Soil erosion models have been used to assist in this task. One of the most commonly used soil erosion models is the Universal Soil Loss Equation (USLE) and its family of models: the Revised Universal Soil Loss Equation (RUSLE), the Revised Universal Soil Loss Equation version 2 (RUSLE2), and the Modified Universal Soil Loss Equation (MUSLE). This paper reviews the different sub-factors of USLE and RUSLE, and analyses how different studies around the world have adapted the equations to local conditions. We compiled these studies and equations to serve as a reference for other researchers working with (R)USLE and related approaches. Within each sub-factor section, the strengths and limitations of the different equations are discussed, and guidance is given as to which equations may be most appropriate for particular climate types, spatial resolution, and temporal scale. We investigate some of the limitations of existing (R)USLE formulations, such as uncertainty issues given the simple empirical nature of the model and many of its sub-components; uncertainty issues around data availability; and its inability to account for soil loss from gully erosion, mass wasting events, or predicting potential sediment yields to streams. Recommendations on how to overcome some of the uncertainties associated with the model are given. Several key future directions to refine it are outlined: e.g. incorporating soil loss from other types of soil erosion, estimating soil loss at sub-annual temporal scales, and compiling consistent units for the fu-
\end{abstract}

ture literature to reduce confusion and errors caused by mismatching units. The potential of combining (R)USLE with the Compound Topographic Index (CTI) and sediment delivery ratio (SDR) to account for gully erosion and sediment yield to streams respectively is discussed. Overall, the aim of this paper is to review the (R)USLE and its sub-factors, and to elucidate the caveats, limitations, and recommendations for future applications of these soil erosion models. We hope these recommendations will help researchers more robustly apply (R)USLE in a range of geoclimatic regions with varying data availability, and modelling different land cover scenarios at finer spatial and temporal scales (e.g. at the field scale with different cropping options).

\section{Introduction}

Soil erosion involves many processes, but the overall effect is of particles being transported and deposited from one location to another. Although it occurs naturally, soil erosion is often exacerbated by anthropogenic activities (Adornado et al., 2009). Soil erosion is affected by wind, rainfall and associated runoff processes, vulnerability of soil to erosion, and the characteristics of land cover and management (David, 1988; Aksoy and Kavvas, 2005; Panagos et al., 2015e). Understanding and mitigating erosion and associated degradation is critical because of its possible effects: nutrient loss, river and reservoir siltation, water quality degradation, and decreases in soil productivity (Bagherzadeh, 2014). In a review of the costs of soil erosion, Pimentel et al. (1995) reported soil erosion rates for regions around the world: 
Asia, South America, and Africa with an average of 30 to $40 \mathrm{tha}^{-1}$ year $^{-1}$ and an average of $17 \mathrm{tha}^{-1}$ year $^{-1}$ for the United States of America and Europe. For comparison, the soil erosion rate for undisturbed forests was reported to range from 0.004 to $0.05 \mathrm{tha}^{-1}$ year $^{-1}$ globally (Pimentel et al., 1995). Within a landscape, erosion due to water can be caused by unconcentrated flow (sheet), occur within channels of concentrated flow (rills and gullies), and occur through raindrop impact and overland flow (inter-rill) (Aksoy and Kavvas, 2005; Morgan, 2005). Land management can be improved through understanding how these erosion processes occur and what areas are vulnerable to soil loss. Advances in technology such as the development of soil erosion models and increases in computing power for spatial analysis have assisted in making soil erosion modelling faster and more accurate.

Soil erosion models aid land management by helping elucidate the areas vulnerable to soil erosion in the baseline scenario, potential erosion rates, and possible causes of soil erosion. They range from relatively simple empirical models, and conceptual models, to more complicated physics-based models (Merritt et al., 2003). Like any other model, there are uncertainties associated with soil erosion models that cannot account for all the complex interactions of sediment delivery. Hence, unless extensive parameterisation and validation against observed data are accomplished, soil loss rates from models should be taken as best available estimates instead of absolute values (Wischmeier and Smith, 1978). Extensive reviews of soil erosion models of varying complexity have been done before but tend to focus on input requirements and applications (Aksoy and Kavvas, 2005; Merritt et al., 2003). A review by de Vente and Posen (2005) differs by focusing on semi-quantitative models that include different types of soil erosion in order to estimate basin sediment yield. Other reviews have focused on the use of different types of soil erosion models in particular places, such as Brazilian watersheds for de Mello et al. (2016).

One family of empirical soil loss models is the Universal Soil Loss Equation (USLE) suite of models, including the original USLE, the Revised Universal Soil Loss Equation (RUSLE), the Revised Universal Soil Loss Equation version 2 (RUSLE2), and the Modified Universal Soil Loss Equation (MUSLE). The USLE is an empirical model used to estimate the annual average rate of soil erosion (tons per unit area) for a given combination of crop system, management practice, soil type, rainfall pattern, and topography. It was originally developed at the plot scale for agricultural plots in the United States of America (Wischmeier and Smith, 1978). An updated form of USLE (RUSLE) was published to include new rainfall erosivity maps for the United States of America and improvements to the method of calculating the different USLE factors (Renard et al., 1997). RUSLE added changes in soil erodibility due to freeze-thaw and soil moisture, a method for calculating cover and management factors, changes to how the influence of topography is incor- porated into the model, and updated values to represent soil conservation practices (Renard and Freimund, 1994). The RUSLE2 framework is a computer interface programmed to handle more complex field situations, including an updated database of factors (Foster et al., 2003). These three variations of (R)USLE measure soil loss per unit area at an annual timescale. The MUSLE is an extension to work at finer temporal resolution, using runoff and peak flow rate to estimate event-based soil loss (Sadeghi et al., 2014). These models have been used around the world due to their relative simplicity and seemingly low data requirements (Table A1).

This simplicity of the (R)USLE has been integrated into more complex soil erosion models to help with management and decision-making, including the Agricultural Non-Point Source model (AGNPS), the Chemical Runoff and Erosion from Agricultural Management Systems model (CREAMS), and the Sediment River Network model (SedNet) (Aksoy and Kavvas, 2005; de Vente and Poesen, 2005; Merritt et al., 2003). The AGNPS estimates upland erosion using the USLE and then uses sediment transport algorithms to simulate runoff and sediment and nutrient transport within watersheds (Aksoy and Kavvas, 2005). The usage of (R)USLE in large models is mainly for the purpose of assisting with decision-making, such as prioritising land use objectives in the Philippines (Bantayan and Bishop, 1998), scenario analysis for water quality in catchments in New Zealand (Rodda et al., 2001), or delineating unique soil landscapes in Australia (Yang et al., 2007).

Extensive reviews of soil erosion modelling and types of soil erosion models have been published that briefly discuss the (R)USLE as an empirical model, elements of which are commonly incorporated into more complex conceptual or physics-based soil erosion models (Aksoy and Kavvas, 2005; de Vente and Poesen, 2005; Merritt et al., 2003). This review is more specific to the (R)USLE and addresses the complexity of its different sub-factors, as well as the issues for researchers to consider before applying (R)USLE to their study area. These issues include equation choices, digital elevation model (DEM) resolution, granularity in land cover characteristics, scale, etc. The MUSLE is not included in this review because Sadeghi et al. (2014) have already done an extensive review of the model and event-scale estimates are beyond the scope of this paper. Annual estimates of soil loss are useful for understanding the baseline erosion in a catchment, but intra-annual and event-based soil loss estimates are useful for elucidating temporal variations in erosion. Performing event-based soil loss modelling is important for areas that frequently experience extreme events as these can cause large-scale sediment transport and mass wasting.

This paper discusses the advantages, disadvantages, and limitations of the USLE model family. Although alternative sub-factor equations are presented, we also discuss questions of suitability that future users should consider before applying these models. The main aim of this paper is to review the 
(Revised) Universal Soil Loss Equation and its sub-factors through the following objectives:

- review the USLE and RUSLE literature to compile equations for the different sub-factors within the (R)USLE;

- provide guidance as to which datasets and equations are appropriate over a range of geoclimatic regions with varying levels of data availability;

- outline the limitations and caveats of the (R)USLE that future users must consider;

- outline potential future directions to overcome these limitations and to improve (R)USLE applications.

\section{Universal Soil Loss Equation (USLE)}

The principal equation for the USLE model family is below:

$A=R \times K \times L \times S \times C \times P$,

where $A$ is mean annual soil loss (metric tons per hectare per year), $R$ is the rainfall and runoff factor or rainfall erosivity factor (megajoule millimetres per hectare per hour per year), $K^{1}$ is the soil erodibility factor (metric ton hours per megajoules per millimetre), $L$ is the slope length factor (unitless), $S$ is the slope steepness factor (unitless), $C$ is the cover and management factor (unitless), and $P$ is the support practice factor (unitless).

The USLE was originally developed at the farm plot scale for agricultural land in the United States of America but has seen use in many other countries, at many other scales, and in many other geoclimatic regions. Although the name implies that the model can be applied to all soils, the original USLE is more accurate for soils with medium texture and slopes of less than $400 \mathrm{ft}$ in length with a gradient ranging between $3 \%$ and $18 \%$, and it is managed with consistent cropping practices that are well represented in plot-scale erosion studies (Wischmeier and Smith, 1978). Hence, applying the USLE family of models to soils and sites exceeding these limits requires careful parameterisation of the model and being mindful of the increased uncertainty in model predictions.

In the original development of the model, this farm plot is called the "unit plot" and is defined as a plot that is $22.1 \mathrm{~m}$ long, is $1.83 \mathrm{~m}$ wide, and has a slope of $9 \%$ (Wischmeier and Smith, 1978). Although the model accounts for rill and interrill erosion, it does not account for soil loss from gullies or mass wasting events such as landslides (Thorne et al., 1985). The Appendix of this paper compiles a non-exhaustive list of studies that have applied the USLE and RUSLE models

\footnotetext{
${ }^{1}$ The RUSLE handbook by Renard et al. (1997) indicates that the $K$-factor metric units are metric tons per hectare per hour per megajoules per hectare per millimetre, but for mathematical correctness the hectare units cancel out.
}

to watersheds around the world. The uncertainties in soil erosion modelling stem from the availability of long-term reliable data, including issues of temporal resolution (e.g. $<30 \mathrm{~min}$ resolution required for (R)USLE) and the availability of spatial data over a catchment. This issue is not unique to (R)USLE applications and is generally worse when applying more complex models with larger numbers of variables and more detailed data requirements (de Vente and Poesen, 2005; Hernandez et al., 2012). Hence, the ubiquitous usage of the (R)USLE can be attributed to its relatively low data requirements compared to more complex soil loss models, making it potentially easier to apply in areas with scarce data. Another limitation of the (R)USLE and arguably many erosion model applications is the lack of validation data with which to verify model outputs, which is discussed further in Sect. 4.

Although the application of the (R)USLE seems to be a simple linear equation at first glance, this review addresses the complex equations that go into calculating its sub-factors, such as rainfall erosivity, which requires detailed pluviographic data $(<30 \mathrm{~min}$ resolution).

\subsection{Rainfall erosivity factor $(R)$}

The $R$ factor represents the effect that rainfall has on soil erosion and was included after observing sediment deposits after an intense storm (Wischmeier and Smith, 1978). The annual $R$ factor is a function of the mean annual $E I_{30}$ that is calculated from detailed and long-term records of storm kinetic energy $(E)$ and maximum 30 min intensity $\left(I_{30}\right)$ (Morgan, 2005; Renard et al., 1997). Due to the detailed data requirements for the standard (R)USLE calculation of rainfall erositivity, studies in areas with less detailed data have used alternative equations depending on the temporal resolution and availability of the rainfall data. These compiled studies have used long-term datasets with at least daily temporal resolution to construct their $R$-factor equation. Extensive work by Naipal et al. (2015) attempted to apply the (R)USLE at a coarse global scale ( 30 arcsec) by using USA and European databases to derive rainfall erosivity equations. These equations use a combination of annual precipitation (millimetres), mean elevation (metres), and simple precipitation intensity index (millimetres per day) to calculate the $R$ factor for different Köppen-Geiger climate classifications (Naipal et al., 2015). Loureiro and Coutinho (2001) used 27 years of daily rainfall data from Portugal and the (R)USLE method of calculating $E I_{30}$ to construct an equation that uses the number of days that received over $10 \mathrm{~mm}$ of rainfall and the amount of rainfall per month when the day's rainfall exceeded $10 \mathrm{~mm}$. The Loureiro and Coutinho (2001) equation was modified by Shamshad et al. (2008) for use in tropical Malaysia by using long-term rainfall data to construct a regression equation relating monthly rainfall and annual rainfall with the $R$ factor. Similarly, Sholagberu et al. (2016) used 23 years of daily rainfall data to create a regression equa- 
tion relating annual rainfall and the $R$ factor for the highlands of Malaysia. These simplified equations may be transferable to areas of similar climate that do not have the longterm detailed rainfall data required by the original (R)USLE. The imperial units of erosivity are in hundreds of foot tonforce (tonf) inch per acre per hour per year, and multiplying by 17.02 will give the SI units of megajoule millimetre per hectare per hour per year (Renard et al., 1997).

With the body of work that has been done in rainfall erosivity, some studies have managed to construct rainfall erosivity maps over large countries and regions. Panagos et al. (2017) have used pluviographic data from 63 countries to calculate rainfall erosivity and spatially interpolated the results to construct a global rainfall erosivity map at 30 arcsec resolution. Despite its coarse resolution, this global dataset can be used as a resource for rainfall erosivity in data-sparse regions. For the United States, Renard et al. (1997) details the procedure for obtaining rainfall erosivity values from their large national database. Renard et al. (1997) would be the recommended reference for study areas in the United States because of the extensive database that already exists for that country. For the European Union, Panagos et al. (2015d) constructed a rainfall erosivity map at $1 \mathrm{~km}$ resolution and published descriptive statistics for $R$ values in each of the member countries. The interpolated map showed good agreement through cross-validation and to previous studies, but areas that had fewer rainfall stations and more diverse terrain caused higher prediction uncertainty (Panagos et al., 2015d). Using a large rainfall dataset, da Silva (2004) constructed a spatially interpolated map of $R$ factors in Brazil whose trends showed agreement with previous work on rainfall erosivity in the country.

In areas that only have annual precipitation available, several equations and their studies can be used as a reference. In their global application, Naipal et al. (2015) published different $R$-factor equations depending on a study area's climate classification. One caveat is that the data for these equations had a large percentage of USA and European records, so resulting accuracy of $R$ factors might be better for those locations (Naipal et al., 2015). In tropical areas such as Southeast Asia, the $R$ factor by El-Swaify et al. (1987) as cited in Merritt et al. (2004) was used extensively in Thailand, the Philippines, and Sri Lanka. However, the units for the $R$ factor in this equation are given as metric tons per hectare per year, which do not correspond to the original units used by (R)USLE (Merritt et al., 2004). This lack of consistency regarding units is not uncommon in the reviewed literature, which sometimes fails to explicitly report the units used for the different factors. For example, Renard and Freimund (1994) report that the units of $R$-factor equations by Arnoldus (1977) were presumed to be in metric units. By being clear and consistent about units in the (R)USLE literature, future researchers can be more certain about the accuracy of their borrowed $R$-factor equations instead of presuming the units to be the same as the original
(R)USLE. Work by Bonilla and Vidal (2011) produced an $R$-factor equation for Chile and published erosivity values similar to those produced by work in areas of similar geography and geology. For New Zealand, Klik et al. (2015) proposed equations for calculating the annual $R$ factor and seasonal $R$ factor with coefficients that change depending on the study area's location within the country.

The usage of monthly precipitation data to determine the $R$ factor is due to monthly rainfall data being more readily available compared to detailed storm records (Renard and Freimund, 1994). Although annual rainfall estimates are sufficient, using monthly rainfall data to construct sub-annual $R$ factors and then aggregating those $R$ factors to an annual scale is useful in sites with large temporal variability in rainfall. Renard and Freimund (1994) used data from 155 stations with known $R$ factors based on the original USLE approach and related their $R$ factors to observed annual and monthly precipitation. These equations developed by Renard and Freimund (1994) on the west coast of USA were used in Ecuador (Ochoa-Cueva et al., 2015), and Honduras and El Salvador (Kim et al., 2005). Work by Arnoldus (1980) developed $R$-factor equations in West Africa that use monthly and annual precipitation. However, as described earlier, these equations present a problem in terms of consistent units. In Southeast Asia, Shamsad et al. (2008) developed an $R$-factor equation in Malaysia that was used in the Philippines by Delgado and Canters (2012). In New Zealand, the monthly precipitation can be aggregated to seasonal precipitation and used in the equation for seasonal $R$ factor derived by Klik et al. (2015).

Monthly or better precipitation records are very useful in (R)USLE applications because of the option of estimating soil loss at a monthly or seasonal scale, which can be useful in countries with high temporal variation of rainfall throughout the year. Monthly and seasonal erosion has been estimated by varying the $R$ factor depending on the monthly precipitation while leaving all the other factors constant (Ferreira and Panagopoulos, 2014; Kavian et al., 2011). Klik et al. (2015) emphasised the need to understand the drivers of soil erosion, including whether rainfall intensity had a stronger effect compared to mean annual rainfall. In an assessment of spatial and temporal variations in rainfall erosivity over New Zealand, December and January were associated with higher erosivities, while August was associated with lowest erosivity (Klik et al., 2015). Similar work by Diodato (2004) has cited the use of monthly erosivity data to be more useful with respect to managing crop growing cycles and tillage practices, especially during seasons where high rainfall erosivity is expected. In locations where there is a large temporal variation in rainfall throughout the year, the seasonal approach of estimating soil erosion is more important for sustainable land management (Ferreira and Panagopoulos, 2014)

To examine how different $R$-factor equations affected predicted soil erosion rates over the same study site, Be- 


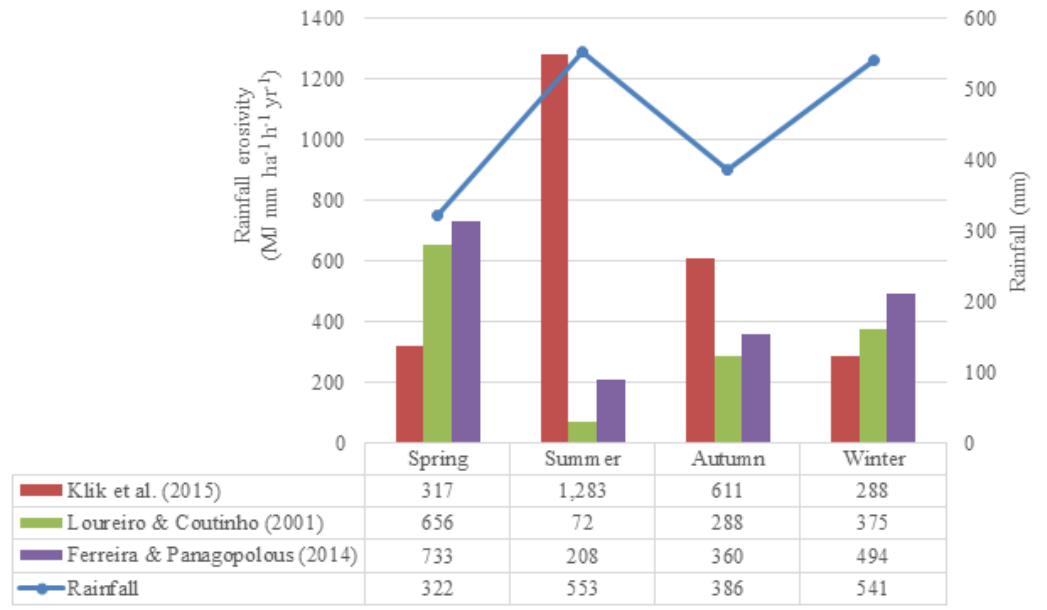

Figure 1. Graph of seasonal rainfall and estimates of erosivity in the Mangatarere watershed (Benavidez, 2018).

Table 1. Annual estimates (Benavidez, 2018) of erosivity in the Mangatarere watershed (megajoule millimetres per hectare per hour per year).

\begin{tabular}{lrrr}
\hline Equation source & Klik et al. (2015) & Loureiro and Coutinho (2001) & Ferreira and Panagopolous (2014) \\
\hline Annual erosivity & 2607 & 1391 & 1715 \\
\hline
\end{tabular}

navidez (2018) tested three different equations over the $\sim$ $157 \mathrm{~km}^{2}$ Mangatarere watershed in New Zealand. The equations by Klik et al. (2015) developed in New Zealand, along with the equations by Loureiro and Coutinho (2001) and Ferreira and Panagopolous (2014) developed in Portugal, were used to estimate annual and seasonal erosivity (Fig. 1 and Table 1). All three equations consider and predict seasonal erosivity, are from similar latitudes, and were developed in temperate to semi-arid environments. For the same set of rainfall data, the three equations predicted different annual and seasonal values of erosivity. Regarding seasonal patterns of erosivity, Klik et al. (2015) predicted highest erosivity occurring during summer but lowest in winter and spring. This trend matches the national observations of the most erosive storms occurring during summer and the least erosive storms occurring during winter (Klik et al., 2015). By contrast, both Loureiro and Coutinho (2001) and Ferreira and Panagopolous (2014) predicted highest erosivity during spring and lowest during summer. This variation is thought to be due to the Portugal equations excluding days below $10.0 \mathrm{~mm}$ of rainfall, which introduces a bias towards the erosive effects of short, intense rainfall events while potentially excluding the erosive power of longer but less intense rainfall events. It is unsurprising that the New Zealand approach performed best in a New Zealand climate, but it does demonstrate the risk of arbitrarily transferring equations between countries, even when geoclimatic conditions are not terribly dissimilar.
These differences highlight the importance of understanding the regional applicability of rainfall erosivity equations. In the reviewed (R)USLE studies for this section, a common occurrence was using equations derived in different countries and regions without much justification regarding why those equations were chosen with little consideration for their suitability. These studies also did not publish any testing of how different $R$ factors produce different erosivity values from the same input dataset. The purpose of testing the different $R$ factors is to illustrate this variation and encourages future users of (R)USLE to do the same sensitivity testing in their area.

In summary, there are many rainfall erosivity datasets and equations in the (R)USLE literature that can be used by new researchers applying the RUSLE to their study area. The erosivity dataset produced by Panagos et al. (2017) is recommended for areas with no rainfall data or in ungauged catchments since this is a raster dataset with global coverage ( $\sim 30$ arcsec resolution) and is freely available. For areas in the European Union, work by Panagos et al. (2015d) has produced a rainfall erosivity map with regional coverage at $\sim 1 \mathrm{~km}$ resolution. These datasets can also be used to validate the erosivity factors calculated at the national or catchment scale. For study areas in which annual precipitation and the Köppen-Geiger classification are known, Naipal et al. (2015) has published rainfall erosivity equations and values for 17 different climate zones. Several studies have published erosivity equations for tropical areas: da Silva (2004) for Brazil, Shamshad et al. (2008) for Malaysia, and Jain and 
Table 2. Summary of different studies that developed rainfall erosivity equations, original locations, and other studies that used their equations.

\begin{tabular}{|c|c|c|c|c|c|}
\hline No. & Author & $\begin{array}{l}\text { Original } \\
\text { location }\end{array}$ & Resolution & Equation and requirements & Other studies \\
\hline 1 & $\begin{array}{l}\text { Wischmeier } \\
\text { and Smith } \\
(1978) \text { and } \\
\text { Renard et } \\
\text { al. (1997) }\end{array}$ & $\begin{array}{l}\text { United States } \\
\text { of America }\end{array}$ & Sub-daily & $\begin{array}{l}R=\frac{\sum_{i=1}^{j}\left(E I_{30}\right)_{i}}{N} \\
E I_{30}=E \times I_{30} \\
E=916+331 \times \log _{10} \mathrm{I} \\
\mathrm{I}: \text { intensity }\left(i n \mathrm{~h}^{-1}\right) \\
E I_{30 i}: E I_{30} \text { for storm } i \\
j: \text { number of storms in an } N \text {-year period } \\
\text { Units } \\
\text { Imperial: } \\
100 \text { foot-ton in acre }{ }^{-1} \mathrm{~h}^{-1} \text { year }^{-1} \\
\text { Metric (multiply by } 17.02): \\
\text { MJ mm ha }{ }^{-1} \mathrm{~h}^{-1} \text { year }^{-1}\end{array}$ & $\begin{array}{l}\text { Applied around } \\
\text { the USA }\end{array}$ \\
\hline 2 & $\begin{array}{l}\text { Mihara (1951) } \\
\text { and Hudson } \\
\text { (1971) as cited } \\
\text { in David (1988) }\end{array}$ & USA & Daily & $\begin{array}{l}R=A \times \sum_{1}^{n} P_{i}^{m} \\
A=0.002 \\
M=2 \\
P_{i}: \text { precipitation total for day } i \text { when } P \text { exceeds } \\
25 \mathrm{~mm} \\
\text { Units: not specified, likely to be original USLE im- } \\
\text { perial units }\end{array}$ & $\begin{array}{l}\text { Watersheds around } \\
\text { the Philippines } \\
\text { (David, 1988) }\end{array}$ \\
\hline 3 & $\begin{array}{l}\text { Arnoldus } \\
(1980) \text { as cited } \\
\text { in Renard } \\
\text { and Freimund } \\
\text { (1994) }\end{array}$ & $\begin{array}{l}\text { Morocco and } \\
\text { other locations } \\
\text { in West Africa }\end{array}$ & $\begin{array}{l}\text { Monthly } \\
\text { and annual }\end{array}$ & 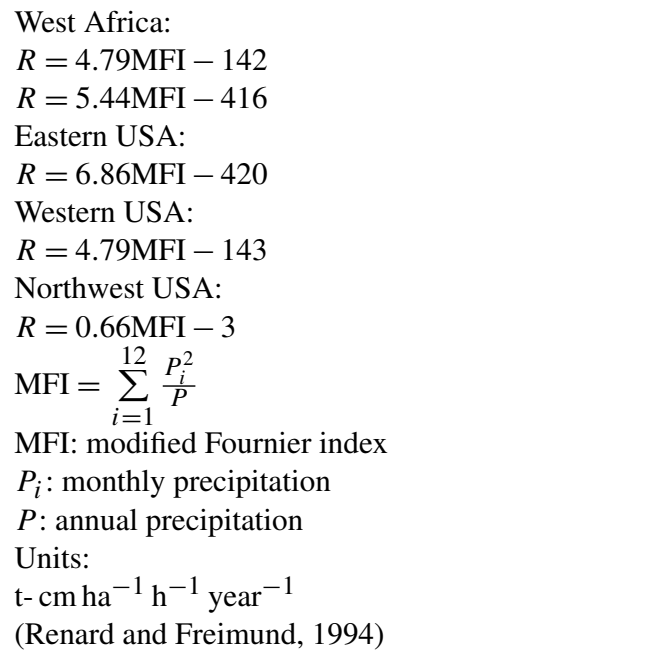 & $\begin{array}{l}\text { Morocco, } \\
\text { Turkey (Demirci } \\
\text { and Karaburun, } \\
\text { 2012); Morocco } \\
\text { (Raissouni et al., } \\
\text { 2016) }\end{array}$ \\
\hline 4 & $\begin{array}{l}\text { Renard and } \\
\text { Freimund } \\
\text { (1994) }\end{array}$ & $\begin{array}{l}\text { West coast } \\
\text { of USA }\end{array}$ & $\begin{array}{l}\text { Monthly } \\
\text { and annual }\end{array}$ & $\begin{array}{l}R=0.0483 \times P^{1.610} \\
R=587.8-1.219 P+0.004105 P^{2} \\
\text { Using MFI }(\text { Arnoldus, } 1980): \\
R=0.07397 \times \mathrm{MFI}^{1.847} \\
R=95.77-6.081 \mathrm{MFI}+0.4770 \mathrm{MFI}^{2} \\
P_{i}: \text { monthly precipitation } \\
P: \text { annual precipitation } \\
\text { Units: MJ mm ha }{ }^{-1} \mathrm{~h}^{-1} \text { year }^{-1}\end{array}$ & $\begin{array}{l}\text { Central America } \\
\text { (Kim et al., 2005); } \\
\text { Iran (Zakerinejad } \\
\text { and Maerker, } \\
\text { 2015); } \\
\text { Ecuador (Ochoa- } \\
\text { Cueva et al., 2015) }\end{array}$ \\
\hline 5 & $\begin{array}{l}\text { Zhou et } \\
\text { al. (1995) } \\
\text { as cited in Li et } \\
\text { al. (2014) }\end{array}$ & Southern China & Monthly & $\begin{array}{l}R=\sum_{i=1}^{12}-1.15527+1.792 P_{i} \\
P_{i}: \text { monthly precipitation } \\
\text { Units: MJ mm ha-1 } \mathrm{h}^{-1} \text { year }^{-1}\end{array}$ & $\begin{array}{l}\text { China } \\
\text { (Li et al., 2014) }\end{array}$ \\
\hline
\end{tabular}


Table 2. Continued.

\begin{tabular}{|c|c|c|c|c|c|}
\hline No. & Author & $\begin{array}{l}\text { Original } \\
\text { location }\end{array}$ & Resolution & Equation and requirements & Other studies \\
\hline 6 & $\begin{array}{l}\text { Roose (1975) } \\
\text { and Morgan } \\
(1974) \text { as cited } \\
\text { in Morgan } \\
(2005)\end{array}$ & $\begin{array}{l}\text { Peninsular } \\
\text { Malaysia and } \\
\text { Africa }\end{array}$ & Annual & $\begin{array}{l}\text { Africa }(\text { Roose }, 1975): \\
R=0.5 \times P \times 17.3 \\
\text { Peninsular Malaysia: } \\
R=(9.28 \times P-8838)\left(\frac{75}{1000}\right) \\
P: \text { mean annual precipitation }(\mathrm{mm}) \\
\text { Units: MJ mm ha }{ }^{-1} \mathrm{~h}^{-1} \text { year }^{-1}\end{array}$ & $\begin{array}{l}\text { Malaysia (Roslee } \\
\text { et al., 2017); Van- } \\
\text { uatu (Dumas and } \\
\text { Fossey, 2009); Iran } \\
\text { (Zakerinejad and } \\
\text { Maerker, 2015) }\end{array}$ \\
\hline 7 & $\begin{array}{l}\text { El-Swaify et } \\
\text { al. (1987) as } \\
\text { cited in Merritt } \\
\text { et al. (2004) }\end{array}$ & $\begin{array}{l}\text { Possibly } \\
\text { Thailand }\end{array}$ & Annual & $\begin{array}{l}R=38.5+0.35 P \\
P: \text { mean annual precipitation } \\
\text { Units: } \text { ha }^{-1} \text { year } \\
\text { been developed to have no units so that the final soil } \\
\text { loss is in } \mathrm{tha}^{-1} \text { year }^{-1} \text { ) }\end{array}$ & $\begin{array}{l}\text { Thailand (Eium- } \\
\text { noh, 2000; Merritt } \\
\text { et al., 2004); Philip- } \\
\text { pines (Adornado } \\
\text { and Yoshida, 2010; } \\
\text { Adornado et al., } \\
\text { 2009; Hernandez } \\
\text { et al., 2012); Sri } \\
\text { Lanka (Jayasinghe } \\
\text { et al., 2010) }\end{array}$ \\
\hline 8 & $\begin{array}{l}\text { Land } \\
\text { Development } \\
\text { Department } \\
\text { (2000) as cited } \\
\text { in } \\
\text { Nontananandh } \\
\text { and Changnoi } \\
\text { (2012) }\end{array}$ & Thailand & Annual & $\begin{array}{l}R=0.04669 P-12.1415 \\
P: \text { mean annual rainfall } \\
\text { Units: } \mathrm{MJ} \mathrm{mm} \mathrm{ha}^{-1} \mathrm{~h}^{-1} \text { year }^{-1}\end{array}$ & $\begin{array}{l}\text { Thailand } \\
\text { (Nontananandh } \\
\text { and } \\
\text { Changnoi, 2012) }\end{array}$ \\
\hline 9 & $\begin{array}{l}\text { Loureiro and } \\
\text { Coutinho } \\
(2001)\end{array}$ & Portugal & Daily & $\begin{array}{l}R=\frac{1}{N} \sum_{i=1}^{N} \sum_{m=1}^{12} E I_{30 \text { (monthly) }} \\
E I_{30} \text { (monthly) }=7.05 \text { rain }_{10}-88.92 \text { days }_{10} \\
\text { Rain }_{10}: \text { monthly rainfall for days with } \geq 10.0 \mathrm{~mm} \\
\text { of rain } \\
\text { Days } 10: \text { monthly number of days with rainfall } \\
\geq 10.0 \mathrm{~mm} \text { of rain } \\
N \text { : number of years } \\
\text { Units: } \mathrm{MJ} \mathrm{mm} \mathrm{ha}^{-1} \mathrm{~h}^{-1} \text { year }^{-1}\end{array}$ & $\begin{array}{l}\text { Spain } \\
\text { (López-Vicente } \\
\text { et al., 2008) }\end{array}$ \\
\hline 10 & $\begin{array}{l}\text { Fernandez et } \\
\text { al. }(2003) \text {, } \\
\text { originally de- } \\
\text { veloped by the } \\
\text { USDA-ARS } \\
(2002)\end{array}$ & USA & Annual & $\begin{array}{l}R=-823.8+5.213 P \\
P: \text { annual precipitation } \\
\text { Units: } \mathrm{MJ} \mathrm{mm} \mathrm{ha}^{-1} \mathrm{~h}^{-1} \text { year }^{-1}\end{array}$ & $\begin{array}{l}\text { USA (Fernandez et } \\
\text { al., 2003); Greece } \\
\text { (Jahun et al., 2015) }\end{array}$ \\
\hline 11 & $\begin{array}{l}\text { Ram et } \\
\text { al. (2004) } \\
\text { as cited in Jain } \\
\text { and Das (2010) }\end{array}$ & India & Annual & $\begin{array}{l}R=81.5+0.38 P \\
P: \text { annual precipitation for areas where annual pre- } \\
\text { cipitation ranges between } 340 \text { and } 3500 \mathrm{~mm} \\
\text { Units: } \mathrm{MJ} \mathrm{mm} \mathrm{ha} \mathrm{mm}^{-1} \mathrm{~h}^{-1} \text { year }^{-1}\end{array}$ & $\begin{array}{l}\text { India } \\
\text { (Jain and Das, } \\
\text { 2010) }\end{array}$ \\
\hline
\end{tabular}


Table 2. Continued.

\begin{tabular}{|c|c|c|c|c|c|}
\hline No. & Author & $\begin{array}{l}\text { Original } \\
\text { location }\end{array}$ & Resolution & Equation and requirements & Other studies \\
\hline 12 & $\begin{array}{l}\text { Shamshad et } \\
\text { al. (2008) }\end{array}$ & Malaysia & $\begin{array}{l}\text { Monthly } \\
\text { and annual }\end{array}$ & $\begin{array}{l}\text { Based on Loureiro and } \\
\text { Coutinho (2001) but for Malaysia: } \\
R=\sum_{i=1}^{12} 6.97 \text { rain }_{10}-11.23 \text { days }_{10} \\
R=\sum_{i=1}^{12} 0.266 \times \text { rain }_{10}^{2.071} \times \text { days }_{10}^{-1.367} \\
R=\sum_{i=1}^{12} 227 \times\left(\frac{P_{i}^{2}}{P}\right)^{0.548} \\
\text { Rain } 10: \text { monthly rainfall for days with } \geq 10.0 \mathrm{~mm} \\
\text { of rain } \\
\text { Days } 10: \text { monthly number of days with rainfall } \\
\geq 10.0 \text { mm of rain } \\
P_{i}: \text { monthly precipitation } \\
P: \text { annual precipitation } \\
\text { Units: MJ mm ha }{ }^{-1} \mathrm{~h}^{-1} \text { year }^{-1}\end{array}$ & $\begin{array}{l}\text { Philippines } \\
\text { (Delgado and Can- } \\
\text { ters, 2012) }\end{array}$ \\
\hline 13 & $\begin{array}{l}\text { Irvem et } \\
\text { al. (2007) }\end{array}$ & Turkey & $\begin{array}{l}\text { Monthly } \\
\text { and annual }\end{array}$ & $\begin{array}{l}R=0.1215 \times \mathrm{MFI}^{2.2421} \\
\mathrm{MFI}=\sum_{i=1}^{12} \frac{P_{i}^{2}}{P} \\
P_{i}: \text { monthly precipitation } \\
P: \text { annual precipitation } \\
\text { Units: MJ mm ha } \mathrm{m}^{-1} \mathrm{year}^{-1}\end{array}$ & $\begin{array}{l}\text { Turkey } \\
\text { (Ozsoy et al., 2012) }\end{array}$ \\
\hline 14 & $\begin{array}{l}\text { Ferreira and } \\
\text { Panagopolous } \\
\text { (2014), similar to } \\
\text { Loureiro } \\
\text { and Coutinho } \\
(2001)\end{array}$ & Portugal & Daily & $\begin{array}{l}R=\sum_{i=1}^{12} 6.56 \text { rain }_{10}-75.09 \text { days }_{10} \\
\text { Rain }_{10}: \text { monthly rainfall for days with } \geq 10.0 \mathrm{~mm} \\
\text { of rain } \\
\text { Days } 10: \text { monthly number of days with rainfall } \\
\geq 10.0 \mathrm{~mm} \text { of rain } \\
\text { Units: } \mathrm{MJ} \mathrm{mm} \mathrm{ha} \mathrm{mm}^{-1} \mathrm{~h}^{-1} \text { year }^{-1}\end{array}$ & $\begin{array}{l}\text { Portugal } \\
\text { (Ferreira and } \\
\text { Panagopoulos, } \\
\text { 2014) }\end{array}$ \\
\hline 15 & $\begin{array}{l}\text { Nakil (2014) as } \\
\text { cited in Nakil } \\
\text { and Khire (2016) }\end{array}$ & India & Annual & $\begin{array}{l}R=839.15 \times e^{0.0008 P} \\
P: \text { annual precipitation } \\
\text { Units: } \mathrm{MJ} \mathrm{mm} \mathrm{ha}^{-1} \mathrm{~h}^{-1} \text { year }^{-1}\end{array}$ & $\begin{array}{l}\text { India } \\
\text { (Nakil and } \\
\text { Khire, 2016) }\end{array}$ \\
\hline 18 & $\begin{array}{l}\text { Naipal et } \\
\text { al. (2015) }\end{array}$ & $\begin{array}{l}\text { Global applica- } \\
\text { tion, but orig- } \\
\text { inal data from } \\
\text { the USA and } \\
\text { Europe }\end{array}$ & Annual & $\begin{array}{l}\text { Various equations depending on Köppen-Geiger } \\
\text { climate classification, including alternate equations } \\
\text { if SDII is not available } \\
P: \text { annual precipitation }(\mathrm{mm}) \\
\text { Z: mean elevation }(\mathrm{m}) \\
\text { SDII: simple precipitation intensity index } \\
\left(\mathrm{mm}^{-1} \text { ) }\right.\end{array}$ & \\
\hline 19 & $\begin{array}{l}\text { Klik et } \\
\text { al. (2015) }\end{array}$ & New Zealand & $\begin{array}{l}\text { Annual or } \\
\text { seasonal }\end{array}$ & $\begin{array}{l}\text { Annual or seasonal: } \\
R=a P^{b} \\
R=a P+b \\
P: \text { annual precipitation }(\mathrm{mm}) \text { or seasonal precipita- } \\
\text { tion (mm) } \\
\text { a and b: constants depending on region of New } \\
\text { Zealand } \\
\text { The equation used will depend on the region of New } \\
\text { Zealand and the season } \\
\text { Units: } \mathrm{MJ} \mathrm{mm} \mathrm{ha}^{-1} \mathrm{~h}^{-1}\end{array}$ & \\
\hline 20 & $\begin{array}{l}\text { Sholagberu et } \\
\text { al. (2016) }\end{array}$ & Malaysia & Annual & $\begin{array}{l}R=0.0003 P^{1.771} \\
P: \text { annual precipitation } \\
\text { Units: } \mathrm{MJ} \mathrm{mm} \mathrm{ha}^{-1} \mathrm{~h}^{-1} \text { year }^{-1}\end{array}$ & \\
\hline
\end{tabular}


Das (2010) for India. For arid areas, Arnoldus (1980) as cited in Renard and Freimund (1994) has derived erosivity equations for Morocco and other locations in West Africa. Many other equations are found in Table 2, and choosing several for sensitivity testing is recommended for future (R)USLE applications. It is also important to test against observed data or $R$ factors derived by previous applications in the same study area or in study areas with similar climatic regimes.

\subsection{Soil erodibility factor $(K)$}

The $K$ factor represents the influence of different soil properties on the slope's susceptibility to erosion (Renard et al., 1997). It is defined as the "mean annual soil loss per unit of rainfall erosivity for a standard condition of bare soil, recently tilled up-and-down slope with no conservation practice" (Morgan, 2005). The $K$ factor essentially represents the soil loss that would occur on the (R)USLE unit plot, which is a plot that is $22.1 \mathrm{~m}$ long, is $1.83 \mathrm{~m}$ wide, and has a slope of $9 \%$ (Lopez-Vicente et al., 2008).

Higher $K$-factor values indicate the soil's higher susceptibility to soil erosion (Adornado et al., 2009). In the (R)USLE, Wischmeier and Smith (1978) and Renard et al. (1997) use an equation that relates textural information, organic matter, information about the soil structure, and profile permeability with the $K$ factor or soil erodibility factor. However, other soil classifications might not include soil structure and profile permeability information that matches the information required by (R)USLE nomograph. Hence, alternative equations have been developed that exclude the soil structure and profile permeability (Table 3 ). The question of which equation to use depends on the availability of soil data. Where only the textural class and organic matter content are known, Stewart et al. (1975) have approximated $K$-factor values based on these inputs. Similar to the $R$ factor, the imperial units of soil erodibility are in ton acre hour per hundreds of acres per foot per tonf per inch. Multiplying by 0.1317 gives the erodibility in SI units of metric tons hectare hour per hectare per megajoule per millimetre (Renard et al., 1997).

Although seemingly relatively straightforward, the $K$ factor equation proposed by Wischmeier and Smith (1978) comes with a few limitations regarding soil type. This equation was developed using data from medium-textured surface soils in the Midwestern USA, with an upper silt fraction limit of $70 \%$ (Renard et al., 1997). An equation for volcanic soils in Hawaii was proposed by El-Swaify and Dangler (1976) as cited in Renard et al. (1997) but is only appropriate for soils similar to Hawaiian soils and not for all tropical soils. Despite these limitations, many studies outside the USA have used the original Wischmeier and Smith (1978) $K$-factor equation (Table 3). Being aware of the regional specificity of $K$-factor equations is important, and using different $K$-factor equations in one study area to find a range of soil erodibility could be a way of testing their applicability.
Similar to the sensitivity analysis of the $R$-factor equations, testing different $K$-factor equations to see the variation in erodibility values and then comparing these $K$ factors with published values from similar soils would be a good way to test applicability. For the spatial coverage of the European Union, a soil erodibility raster dataset $(\sim 500 \mathrm{~m}$ resolution) is available for validation (Panagos et al., 2014). David (1988) and Dymond (2010) have published $K$-factor values for soils of different textural classes (e.g. clay, loam) that can be used if only soil texture is known (Tables 4 and 5). However, the values published by Dymond (2010) are broad and do not account for soils with mixed texture, while the values of David (1988) are based on soils in the Philippines. Like the $R$ factor, it is important to check the derived $K$-factor values for the site-specific soil against previously published $K$ factor values for comparable sites and soil types.

\subsection{Slope length $(L)$ and steepness $(S)$ factor}

The $L S$ factor represents the effect of the slope's length and steepness on sheet, rill, and inter-rill erosion by water, and it is the ratio of expected soil loss from a field slope relative to the original USLE unit plot (Wischmeier and Smith, 1978). The USLE method of calculating the slope length and steepness factor was originally applied at the unit plot and field scale, and the RUSLE extended this to the onedimensional hill slope scale, with different equations depending on whether the slope had a gradient of more than $9 \%$ (Renard et al., 1997; Wischmeier and Smith, 1978). Further research extends the $L S$ factor to topographically complex units using a method that incorporates contributing area and flow accumulation (Desmet and Govers, 1996). The USLE and RUSLE method of calculating the $L S$ factor uses slope length, angle, and a parameter that depends on the steepness of the slope in percent (Wischmeier and Smith, 1978).

One of the criticisms of the original USLE method of calculating $L S$ factor is its limited applicability to complex topography. With advances in GIS technology, the method of determining the $L S$ factor as a function of upslope contributing area or flow accumulation and slope has risen in popularity (Table 6). The use of DEMs to calculate the upslope contributing area and the resulting $L S$ factor allows researchers to account for more topographically complex landscapes (Moore and Burch, 1986; Desmet and Govers, 1996). Desmet and Govers (1996) have also built on this method through showing its application in a GIS environment over topographically complex terrain when compared to the original method proposed by Wischmeier and Smith (1978). This method of using flow accumulation for slope length and steepness explicitly accounts for convergence and divergence of flow, which is important when considering soil erosion over a complex landscape (Wilson and Gallant, 2000). It is possible to use this method to calculate the $L S$ factor over a large extent, but a high-resolution DEM is needed for accurate representation of the topography. The resolution required 
Table 3. Summary of different studies with soil erodibility equations, original locations, and other studies that used their equations. All of the equations in Table 3 use imperial units of soil erodibility: ton acre hour per hundreds of acres per foot per tonf per inch. Multiply by 0.1317 for conversion into SI units of metric ton hours per megajoules per millimetre.

\begin{tabular}{|c|c|c|c|c|c|}
\hline No. & Author & $\begin{array}{l}\text { Original } \\
\text { location }\end{array}$ & Data requirements & Equation & Other studies \\
\hline 1 & $\begin{array}{l}\text { Wischmeier } \\
\text { and Smith } \\
(1978) \text { and } \\
\text { Renard et } \\
\text { al. (1997) }\end{array}$ & USA & $\begin{array}{l}\text { Very fine sand }(\%) \text {, } \\
\text { clay }(\%) \text {, silt }(\%) \text {, } \\
\text { organic matter }(\%) \text {, } \\
\text { soil structure, pro- } \\
\text { file permeability }\end{array}$ & $\begin{array}{l}M=\text { Silt } \times(100-\text { Clay }) \\
K=\left\{\left[2.1 \times M^{1.14} \times\left(10^{-4}\right) \times(12-a)\right]\right. \\
+[3.25 \times(b-2)]+[2.5 \times(c-3)]\} \div 100 \\
M \text { : Particle-size parameter } \\
\text { Silt: silt }(\%) \text { as well as the percentage of very fine } \\
\text { said }(0.1 \text { to } 0.05 \mathrm{~mm}) \\
\text { Clay: clay }(\%) \\
a \text { : } \text { organic matter }(\%) \\
b \text { : soil structure code used in soil classification: } \\
\text { 1: Very fine granular } \\
\text { 2: Fine granular } \\
\text { 3: Medium or coarse granular } \\
\text { 4: Blocky, platy, or massive } \\
c \text { : profile permeability class: } \\
\text { 1: Rapid } \\
\text { 2: Moderate to rapid } \\
\text { 3: Moderate } \\
\text { 4: Slow to moderate } \\
\text { 5: Slow } \\
\text { 6: Very slow }\end{array}$ & $\begin{array}{l}\text { Thailand } \\
\text { (Eiumnoh, 2000); } \\
\text { Vanuatu (Du- } \\
\text { mas and Fossey, } \\
\text { 2009); Philippines } \\
\text { (Schmitt, 2009); } \\
\text { India (Jain and Das, } \\
\text { 2010); Turkey (Oz- } \\
\text { soy et al., 2012); } \\
\text { Iran (Bagherzadeh, } \\
\text { 2014); Portugal } \\
\text { (Ferreira and } \\
\text { Panagopoulos, } \\
\text { 2014); China } \\
\text { (Li et al., 2014); } \\
\text { European Union } \\
\text { (Panagos et al., } \\
\text { 2014) }\end{array}$ \\
\hline 2 & $\begin{array}{l}\text { Williams and } \\
\text { Renard (1983) } \\
\text { as cited in Chen } \\
\text { et al. (2011) }\end{array}$ & USA & $\begin{array}{l}\text { Sand }(\%) \text {, silt }(\%) \text {, } \\
\text { clay }(\%) \text {, organic } \\
\text { carbon }(\%)\end{array}$ & $\begin{array}{l}K=0.2+0.3 \exp \left(0.0256 \times \mathrm{Sa} \times\left(1-\frac{\mathrm{Si}}{100}\right)\right) \\
\times\left(\frac{\mathrm{Si}}{\mathrm{Cl}+\mathrm{Si}}\right)^{0.3} \times\left(1.0-\frac{0.25 \times \mathrm{C}}{\mathrm{C}+\exp (3.72-2.95 \mathrm{C})}\right) \\
\times\left(1.0-\frac{0.7 \times \mathrm{SN}}{\mathrm{SN}+\exp (-5.51+22.9 \mathrm{SN})}\right) \\
\mathrm{Sa}: \text { sand }(\%) \\
\mathrm{Si} \text { silt }(\%) \\
\mathrm{Cl}: \text { clay }(\%) \\
\mathrm{SN}=1-(\mathrm{Sa} / 100) \\
\mathrm{C}: \text { organic carbon }\end{array}$ & $\begin{array}{l}\text { China } \\
\text { (Chen et al., } \\
\text { 2011) }\end{array}$ \\
\hline 3 & $\begin{array}{l}\text { David (1988), } \\
\text { a simplified } \\
\text { version of } \\
\text { Wischmeier } \\
\text { and Mannering } \\
\text { (1969) }\end{array}$ & USA & $\begin{array}{l}\text { Sand }(\%), \text { clay }(\%), \\
\text { silt }(\%), \text { organic } \\
\text { matter }(\%), p H\end{array}$ & $\begin{array}{l}K=[(0.043 \times \mathrm{pH})+(0.62 \div \mathrm{OM}) \\
+(0.0082 \times \mathrm{S})-(0.0062 \times \mathrm{C})] \times \mathrm{Si} \\
\mathrm{pH}: \mathrm{pH} \text { of the soil } \\
\text { OM: organic matter }(\%) \\
\mathrm{S}: \text { sand content }(\%) \\
\text { C: clay ratio }=\% \text { clay } /(\% \text { sand }+\% \text { silt }) \\
\text { Si: silt content }=\% \text { silt } / 100\end{array}$ & $\begin{array}{l}\text { Philippines } \\
\text { (David, 1988; } \\
\text { Hernandez et al., } \\
\text { 2012) }\end{array}$ \\
\hline 4 & $\begin{array}{l}\text { El-Swaify and } \\
\text { Dangler (1976) } \\
\text { as cited in } \\
\text { Renard et } \\
\text { al. (1997) }\end{array}$ & $\begin{array}{l}\text { Hawaii, } \\
\text { USA }\end{array}$ & $\begin{array}{l}\text { Textural } \\
\text { information, base } \\
\text { saturation }\end{array}$ & $\begin{array}{l}K=-0.03970+0.00311 x_{1}+0.00043 x_{2}+ \\
0.00185 x_{3}+0.00258 x_{4}-0.00823 x_{5} \\
x_{1}: \text { unstable aggregate size fraction }(<0.250 \mathrm{~mm}) \\
(\%) \\
x_{2}=\text { modified silt }(0.002-0.1 \mathrm{~mm})(\%) \cdot \text { modified } \\
\text { sand }(0.1-2 \mathrm{~mm})(\%) \\
x_{3}: \% \text { base saturation } \\
x_{4}: \text { silt fraction }(0.002-0.050 \mathrm{~mm})(\%) \\
x_{5}: \text { modified sand fraction }(0.1-2 \mathrm{~mm})(\%)\end{array}$ & \\
\hline
\end{tabular}


Table 4. $K$-factor values from Dymond (2010) for soil textures in New Zealand.

\begin{tabular}{lr}
\hline Soil texture & $K$ factor (Dymond, 2010) \\
\hline Clay & 0.20 \\
Loam & 0.25 \\
Sand & 0.05 \\
Silt & 0.35 \\
\hline
\end{tabular}

Table 5. $K$-factor values from David (1988) for soil textures in the Philippines.

\begin{tabular}{lr}
\hline Soil texture & $K$ factor (David, 1988) \\
\hline Loamy fine sand & 0.07 \\
Clay & $0.13-0.26$ \\
Clay loam & $0.22-0.30$ \\
Loam & $0.19-0.63$ \\
Sandy clay & $0.09-0.20$ \\
Sandy loam & $0.23-0.30$ \\
Silt loam & $0.30-0.60$ \\
Silty clay & $0.19-0.27$ \\
Silty clay loam & $0.28-0.35$ \\
\hline
\end{tabular}

depends on the study area's scale. The relatively coarse globally available DEMs ( $\sim 30 \mathrm{~m}$ at best) are less suited to field and sub-catchment scale studies where it may be important to capture effects of micro-topography.

The original equations for the $L S$ factor assume that slopes have uniform gradients and any irregular slopes would have to be divided into smaller segments of uniform gradients for the equations to be more accurate (Wischmeier and Smith, 1978). At the plot or small field scale, this manual measurement of slopes and dividing into segments may be manageable, but it is less useful at larger scales. In terms of practicality, Desmet and Govers (1996) have reported studies of this method applied at a watershed scale with the disadvantages of it being time-consuming. Studies in Iran and the Philippines have implemented the (R)USLE methods within a GIS environment by calculating the $L S$ factor for each raster cell in a DEM, essentially treating each pixel as its own segment of uniform slope (Bagherzadeh, 2014; Schmitt, 2009).

As explained above, the method of using flow accumulation, upslope contributing area, and slope in a GIS environment has gained popularity due to its ability to explicitly account for convergence and divergence of flow, thus capturing more complex topography (Wilson and Gallant, 2000). The flow accumulation method was applied at the scales of watersheds and regions (as shown in Table 6) and has even been applied by Panagos et al. (2015a) at the scale of the European Union using a $25 \mathrm{~m}$ DEM. The only thing limiting users is the availability of high-resolution DEMs and the trade-off between processing time and accuracy. The original
(R)USLE methods require only slope angle and length, operate over a single cell in a DEM by treating it as a uniform slope, and take less processing time compared to the method using flow accumulation. However, the user must remember that this cannot capture the convergence and divergence of flow and thus sacrifices accuracy for time.

Additionally, the issue of limited vertical accuracy in global and many national DEMs confounds the uncertainties associated with coarse cell sizes. Further work on understanding the appropriate horizontal resolution and vertical accuracy of DEMs used for soil erosion predictions at the sub-catchment or field scales is suggested.

Benavidez (2018) investigated use of high-resolution DEMs (15 $\mathrm{m}$ and finer), finding the methods that only used slope length and steepness were adequate at delineating large vulnerable areas at the watershed scale. However, the methods using flow accumulation performed significantly better at the sub-watershed or field scale (Benavidez, 2018).

In summary, the choice of which $L S$-factor method to use is dependent on the spatial resolution of the DEM, availability of computing resources, and scale of the study site. DEms with spatial resolution coarser than $\sim 100 \mathrm{~m}$ do not accurately capture the flow network of a catchment (Panagos et al., 2015a). The $L S$-factor methods that account for only slope length and steepness are recommended for sites with such coarse DEMs. At the national, regional, or watershed scale, delineating large areas vulnerable to soil loss is more useful due to the ease of managing these areas at such large scales, and the methods that use only slope length and steepness are recommended. For sub-watershed or field studies and with sufficiently fine DEMs ( $\sim 15 \mathrm{~m}$ or finer), using $L S$-factor methods that account for flow accumulation are more useful for identifying the most critical areas of vulnerability for targeted management approaches.

\subsection{Cover and management factor $(C)$}

The cover and management factor $(C)$ is defined as the ratio of soil loss from a field with a particular cover and management to that of a field under "clean-tilled continuous fallow" (Wischmeier and Smith, 1978). The (R)USLE uses a combination of sub-factors such as impacts of previous management, canopy cover, surface cover and roughness, and soil moisture on potential erosion to produce a value for the soil loss ratio, which is used with the $R$ factor to produce a value for the $C$ factor (Renard et al., 1997). This method requires extensive knowledge of the study area's cover characteristics including agricultural management and may be suitable at the field or farm scale, but monitoring all these characteristics at the watershed scale may not be feasible.

A simpler method of determining the $C$ factor is referencing studies that have reported values for similar land cover, or from studies done in the same area or region. Tables 8 and 9 give a broad overview of $C$ factors for different cover types and common crops. Wischmeier and Smith (1987) also in- 
Table 6. Summary of methods of calculating $L S$ factor, original locations, and other studies that used these methods.

\begin{tabular}{|c|c|c|c|c|c|}
\hline No. & Author & $\begin{array}{l}\text { Original } \\
\text { location }\end{array}$ & $\begin{array}{l}\text { Data } \\
\text { requirements }\end{array}$ & Equation & Other studies that utilised similar methods \\
\hline 1 & $\begin{array}{l}\text { Wischmeier and } \\
\text { Smith (1978) }\end{array}$ & USA & $\begin{array}{l}\text { Slope length } \\
\text { and angle }\end{array}$ & $\begin{array}{l}L S=\left(\frac{\lambda}{72.6}\right)^{m} \times\left[\left(65.41 \times \sin ^{2} \theta\right)\right. \\
+(4.56 \times \sin \theta)+0.065] \\
\lambda: \text { slope length }(\mathrm{ft}) \\
\Theta: \text { angle of slope } \\
m: \text { dependent on the slope } \\
-0.5 \text { if slope }>5 \% \\
-0.4 \text { if slope is between } 3.5 \% \text { and } 4.5 \% \\
-0.3 \text { if slope is between } 1 \% \text { and } 3 \% \\
-0.2 \text { if slope is less than } 1 \%\end{array}$ & $\begin{array}{l}\text { Thailand (Eiumnoh, 2000; Merritt et al., 2004); } \\
\text { Vanuatu (Dumas and Fossey, 2009); Iran } \\
\text { (Bagherzadeh, 2014) }\end{array}$ \\
\hline 2 & Renard et al. (1997) & USA & $\begin{array}{l}\text { Slope length } \\
\text { and angle }\end{array}$ & $\begin{array}{l}L=\left(\frac{\lambda}{72.6}\right)^{m} \\
m=\frac{\beta}{1+\beta} \\
\beta=\frac{\left(\frac{\sin \theta}{0.08966}\right)}{\left[3.0 \times(\sin \theta)^{0.8}+0.56\right]} \\
\text { If slope is less than } 9 \% \text { : } \\
S=10.8 \times \sin \theta+0.03 \\
\text { If slope is greater or equal to } 9 \% \text { : } \\
S=16.8 \times \sin \theta-0.50 \\
\text { But if the slope is shorter than } 15 \mathrm{ft}: \\
S=3.0 \times(\sin \theta)^{0.8}+0.56 \\
\lambda: \text { slope length }(\mathrm{ft}) \\
\Theta: \text { angle of slope } \\
m: \text { dependent on the slope } \\
-0.5 \text { if slope }>5 \% \\
-0.4 \text { if slope is between } 3.5 \% \text { and } 4.5 \% \\
-0.3 \text { if slope is between } 1 \% \text { and } 3 \% \\
-0.2 \text { if slope is less than } 1 \%\end{array}$ & $\begin{array}{l}\text { Philippines (Schmitt, 2009); China (Li et al., 2014); } \\
\text { Thailand (Nontananandh and Changnoi, 2012); } \\
\text { Turkey (Ozsoy et al., 2012) }\end{array}$ \\
\hline 3 & $\begin{array}{l}\text { David (1988), } \\
\text { based on work by } \\
\text { Madarcos (1985) } \\
\text { and Smith and } \\
\text { Whitt (1947) }\end{array}$ & $\begin{array}{l}\text { Philippines, but } \\
\text { based on work } \\
\text { from the USA }\end{array}$ & $\begin{array}{l}\text { Slope rise in } \\
\text { percent }\end{array}$ & $\begin{array}{l}L S=a+b \times S_{L}^{4 / 3} \\
a=0.1 \\
b=0.21 \\
S_{L}: \text { slope }(\%)\end{array}$ & Philippines (David, 1988) \\
\hline 4 & $\begin{array}{l}\text { Morgan (2005) } \\
\text { but previously } \\
\text { published in earlier } \\
\text { editions }\end{array}$ & Britain & $\begin{array}{l}\text { Slope length } \\
\text { and gradient in } \\
\text { percent }\end{array}$ & $\begin{array}{l}L S=\left(\frac{l}{22}\right)^{0.5}\left(0.065+0.045 s+0.0065 s^{2}\right) \\
l: \text { slope length }(\mathrm{m}) \\
s: \text { slope steepness }(\%)\end{array}$ & $\begin{array}{l}\text { India (Nakil and Khire, 2016; Sinha and Joshi, } \\
\text { 2012); Greece (Rozos et al., 2013) }\end{array}$ \\
\hline 5 & $\begin{array}{l}\text { Moore and Burch } \\
\text { (1986) as cited } \\
\text { in Mitasova } \\
\text { et al. (1996) } \\
\text { Desmet and Govers } \\
\text { (1996); Mitasova et } \\
\text { al. (2013); }\end{array}$ & USA & $\begin{array}{l}\text { Upslope con- } \\
\text { tributing area } \\
\text { per unit width, } \\
\text { which can be } \\
\text { approximated } \\
\text { through flow } \\
\text { accumulation, } \\
\text { cell size, slope }\end{array}$ & $\begin{array}{l}L S=(m+1)\left(\frac{U}{L_{0}}\right)^{m}\left(\frac{\sin \beta}{S_{0}}\right)^{n} \\
U\left(\mathrm{~m}^{2} \mathrm{~m}^{-1}\right) \text { : upslope contributing area per } \\
\text { unit width as a proxy for discharge } \\
U=\text { flow accumulation } \times \text { cell size } \\
L_{0}: \text { length of the unit plot }(22.1) \\
S_{0}: \text { slope of unit plot }(0.09) \\
\beta: \text { slope } \\
m \text { (sheet) and } n \text { (rill) depend on the prevail- } \\
\text { ing type of erosion ( } m=0.4 \text { to } 0.6) \text { and } n \\
(1.0 \text { to } 1.3)\end{array}$ & $\begin{array}{l}\text { Philippines (Adornado and Yoshida, 2010; Ador- } \\
\text { nado et al., 2009); Sri Lanka (Jayasinghe et al., } \\
\text { 2010); China (Chen et al., 2011); Iran (Zaker- } \\
\text { inejad and Maerker, 2015); Jordan (Farhan and } \\
\text { Nawaiseh, 2015); Morocco (Raissouni et al., 2016); } \\
\text { New Zealand (Fernandez and Daigneault, 2016). } \\
\text { Similar methods from Moore and Burch (1986): } \\
\text { India (Jain and Das, 2010); Portugal (Ferreira and } \\
\text { Panagopoulos, 2014); Greece (Jahun et al., 2015); } \\
\text { India (Nakil and Khire, 2016). } \\
\text { Similar methods from Desmet and Govers (1996): } \\
\text { USA (Boyle et al., 2011); Turkey (Demirci and } \\
\text { Karaburun, 2012); Philippines (Delgado and Can- } \\
\text { ters, 2012). }\end{array}$ \\
\hline
\end{tabular}

clude the effect of percent ground cover, reporting $C$-factor values for the same cover type over a range of cover percentage and condition. Morgan (2005) and David (1988) have reported values for the different growth stages of the same types of trees. A simple method of creating a $C$-factor layer is by using lookup tables to assign $C$-factor values to the land cover classes present in the study area. When using $C$ factors from the literature, it is important to note that the definition of land cover type between two countries may vary. For exam- ple, land classified as forest in one country may be different in terms of vegetation cover or type compared to forest in another country (e.g. differences in pine forests and tropical forests). Therefore, it is crucial to understand the differences between land cover classifications before applying $C$-factor values from the literature. Van der Knijff et al. (2000) cites the large spatial and temporal variations in cover and crop over a large region such as the European Union as another 
Table 7. $C$-factor equations that use NDVI.

\begin{tabular}{|c|c|c|c|c|}
\hline No. & Author & Original location & Equation & \\
\hline 1 & $\begin{array}{l}\text { Van der Knijff et } \\
\text { al. }(2000)\end{array}$ & Europe & $\begin{array}{l}C=\exp \left[\propto\left(\frac{\mathrm{NDVI}}{\beta-\mathrm{NDVI}}\right)\right] \\
\alpha=2 \\
\beta=1\end{array}$ & \\
\hline 2 & $\begin{array}{l}\text { Ma et } \\
\text { al. }(2010) \\
\text { as cited in Li et } \\
\text { al. }(2014)\end{array}$ & China & $\begin{array}{l}f_{g}=\frac{\mathrm{NDVI}-\mathrm{NDVI} \mathrm{I}_{\min }}{\mathrm{NDVI}_{\max }-\mathrm{NDV}_{\min }} \\
1 \\
C=\left\{\begin{array}{c} \\
0.6508-0.343 \times \log ?\left(f_{g}\right) \\
0\end{array}\right.\end{array}$ & $\begin{array}{c}f_{g}=0 \\
0<f_{g}<78.3 \% \\
f_{g} \geq 78.3 \%\end{array}$ \\
\hline
\end{tabular}

Table 8. $C$ factors for general types of land cover compiled from various sources.

\begin{tabular}{|c|c|c|c|c|c|c|}
\hline Cover & $\begin{array}{r}\text { Dymond } \\
(2010) \\
\text { (New } \\
\text { Zealand) }\end{array}$ & $\begin{array}{c}\text { David (1988) } \\
\text { (Philippines) }\end{array}$ & $\begin{array}{r}\text { Morgan } \\
(2005) \\
\text { (various) }\end{array}$ & $\begin{array}{r}\text { Fernandez et al. } \\
\text { (2003) } \\
\text { (USA) }\end{array}$ & $\begin{array}{r}\text { Dumas and } \\
\text { Fossey (2009) } \\
\text { (Vanuatu) }\end{array}$ & $\begin{array}{r}\text { Land Development Department } \\
(2002) \\
\text { as cited in Nontananandh } \\
\text { and Changnoi (2012) }\end{array}$ \\
\hline Bare ground & 1 & 1 & 1 & & & \\
\hline Urban & & 0.2 & & 0.03 & 0 & 0 \\
\hline Crop & & & & 0.128 & 0.01 & $0.255-0.525$ \\
\hline Forest & 0.005 & $0.001-0.006$ & 0.001 & 0.001 & 0.001 & $0.003-0.048$ \\
\hline Pasture & 0.01 & & 0.1 & & & \\
\hline Scrub & 0.005 & $0.007-0.9$ & 0.01 & 0.003 & 0.16 & $0.01-0.1$ \\
\hline
\end{tabular}

reason why using the lookup-table-based approach is inadequate and tedious.

To address this, another method of determining the $C$ factor is through the normalized difference vegetation index (NDVI) estimated from satellite imagery. Although there are NDVI layers available, these are limited by geographical coverage, date of acquisition, and resolution. The MODIS NDVI dataset made by Caroll et al. (2004) at $250 \mathrm{~m}$ resolution covers the USA and South America ${ }^{2}$. NASA produced a global dataset of NDVI values at $1^{\circ}$ resolution for the time span of July 1983 to June 1984, making it suitable for studying historical soil erosion but not necessarily for the current state of land cover ${ }^{3}$.

In areas where ready-made NDVI products are unavailable, authors have used satellite imagery to obtain NDVI such as AVHRR or Landsat ETM (Van der Knijff et al., 2000; De Asis and Omosa, 2007; Ma et al., 2010, as cited in Li et al., 2014). De Asis and Omasa (2007) related the $C$ factor and NDVI through fieldwork and image classification - determining the $C$ factor at several points within the study area using the (R)USLE approach and relating it to the NDVI through regression correlation analysis. This may not be feasible in larger study areas such as the European Union, where Van der Knijff et al. (2000) determined NDVI from satel-

\footnotetext{
${ }^{2}$ http://glcf.umd.edu/data/ndvi/ (last access: 12 November 2018)

${ }^{3}$ https://data.giss.nasa.gov/landuse/ndvi.html (last access: 12 November 2018)
}

lite imagery and created an equation based on its positive correlation with green vegetation (Table 7). This approach enabled them to create a $C$-factor map over the European Union. However, $C$ factors were unrealistically high in some areas such as woodland and grassland, so values for those areas were taken from the literature.

An advantage of using NDVI is that researchers can determine sub-annual $C$ factors if there is satellite imagery available, which can lead to understanding the contribution of cover to seasonal soil erosion and identifying critical periods within the year where soil erosion is a risk (Ferreira and Panagopoulos, 2014). Similar methods have been applied in Brazil by Durigon et al. (2014), Greece by Alexandridis et al. (2015), and Kyrgyzstan by Kulikov et al. (2016). Determining $C$ factors at the seasonal scale is important because vegetation cover can change throughout the year due to agricultural and forestry practices. In study areas with a high temporal variation of rainfall throughout the year, seasonal vegetation can play a big part in exacerbating or mitigating soil erosion.

To summarise, the choice of which method to use depends on the scale of the study area, reported $C$ factors for similar cover, and availability of high-resolution imagery. For small-scale studies, it is more feasible to determine the $C$ factors through fieldwork. If previous (R)USLE studies have reported $C$ factors for cover similar to the study area, those values can be used for the table-based approach. Lastly, highresolution imagery can be used to determine the study area's 
Table 9. $C$ factors for specific types of land cover compiled from various sources.

\begin{tabular}{|c|c|c|c|}
\hline Cover & $\begin{array}{r}\text { Panagos et al. (2015b) } \\
\text { (Europe) }\end{array}$ & $\begin{array}{r}\text { David (1988) } \\
\text { (Philippines) }\end{array}$ & $\begin{array}{r}\text { Morgan (2005) } \\
\text { (various) }\end{array}$ \\
\hline Bananas & & $0.1-0.3$ & \\
\hline Barley & 0.21 & & \\
\hline Chili & & & 0.33 \\
\hline Cocoa & & & $0.1-0.3$ \\
\hline Coffee & & & $0.1-0.3$ \\
\hline Common wheat and spelt & 0.2 & & $0.1-0.4$ \\
\hline Cotton seed & 0.5 & $0.4-0.6$ & $0.4-0.7$ \\
\hline Dried pulses (legumes) and protein crop & 0.32 & $0.3-0.5$ & $0.04-0.7$ \\
\hline Durum wheat & 0.2 & & \\
\hline Fallow land & 0.5 & & \\
\hline Grain - maize/corn & 0.38 & $0.3-0.6$ & $0.02-0.9$ \\
\hline Groundnuts & & & $0.3-0.8$ \\
\hline Linseed & 0.25 & & $0.1-0.2$ \\
\hline Oilseeds & 0.28 & & \\
\hline Palm with cover crops & & $0.05-0.3$ & $0.1-0.3$ \\
\hline Pineapple & & $0.2-0.5$ & $0.01-0.4$ \\
\hline Potatoes & 0.34 & & $0.1-0.4$ \\
\hline Rape and turnip rape & 0.3 & & \\
\hline Rice & 0.15 & $0.1-0.2$ & $0.1-0.2$ \\
\hline Rye & 0.2 & & \\
\hline Soya & 0.28 & & $0.2-0.5$ \\
\hline Sugar beet & 0.34 & & \\
\hline Sugarcane & & & $0.13-0.4$ \\
\hline Sunflower seed & 0.32 & & \\
\hline Tobacco & 0.49 & $0.4-0.6$ & \\
\hline Yams & & & $0.4-0.5$ \\
\hline
\end{tabular}

Table 10. Examples of where $C$ factor accounts for crop management from Morgan (2005) and David (1988).

\begin{tabular}{llr}
\hline Crop & Management & $C$ factor \\
\hline Maize, sorghum, or millet & High productivity; conventional tillage & $0.20-0.55$ \\
& Low productivity; conventional tillage & $0.50-0.90$ \\
& High productivity; chisel ploughing into residue & $0.12-0.20$ \\
& Low productivity; chisel ploughing into residue & $0.30-0.45$ \\
& High productivity; no or minimum tillage & $0.02-0.10$ \\
\hline Coconuts & Tree intercrops & $0.05-0.1$ \\
& Annual crops as intercrop & $0.1-0.30$ \\
\hline
\end{tabular}

NDVI. At small scales and with a good understanding of differences in land cover classifications, pulling values from the literature may be the most efficient choice, but at larger regional scales this may become tedious. At larger scales, highresolution satellite imagery may be available to determine NDVI, but authors must be mindful of its acquisition date in relation to their study period, as well as data quality and image processing issues such as dealing with cloud cover and aggregating images from multiple satellite passes (Van der Knijff et al., 2000; Kulikov et al., 2016).

\subsection{Support practice factor $(P)$}

The support practice factor $(P)$ is defined as the ratio of soil loss under a specific soil conservation practice (e.g. contouring, terracing) to that of a field with upslope and downslope tillage (Renard et al., 1997). The $P$ factor accounts for management practices that affect soil erosion through modifying the flow pattern, such as contouring, strip cropping, or terracing (Renard et al., 1997). The more effective the conservation practice is at mitigating soil erosion, the lower the $P$ factor (Bagherzadeh, 2014). Like the $C$ factor, values for $P$ factors can be taken from the literature; if there are no sup- 
port practices observed, the $P$ factor is 1.0 (Adornado et al., 2009). The $P$ factor can also be estimated using sub-factors, but the difficulty of accurately mapping support practice factors or not observing support practices leads to many studies ignoring it by giving their $P$ factor a value of 1.0 as seen in Appendix A1 (Adornado et al., 2009; Renard et al., 1997; Schmitt, 2009).

Another possible reason why studies may ignore the $P$ factor is due to the nature of their chosen $C$ factors. Some $C$ factors already account for the presence of a support factor such as intercropping or contouring. For example, Morgan (2005) and David (1988) give $C$ factors for one type of crop, but with different types of management (Table 10). Despite the $P$ factor being commonly ignored, a number of studies have reported possible $P$ factors for different kinds of tillage, terracing, contouring, and strip cropping (Table 11). The $P$ factor has a significant impact on the estimation of soil loss. For example, a $P$ factor of 0.25 for zoned tillage reflects the potential for this management factor to reduce soil by $75 \%$ loss compared to conventional tillage ( $P$ factor: 1.00 ). At suitably detailed scales and with enough knowledge of farming practices, using these $P$ factors may lead to a more accurate estimation of soil loss. Additionally, these $P$ factors can be used in scenario analysis to understand how changing farming practices may mitigate or exacerbate soil loss. An application of (R)USLE in the Cagayan de Oro catchment in the Philippines showed, through scenario analysis, that soil conservation practices such as agroforestry and alley cropping could potentially lead to large decreases in soil loss compared to the baseline scenario (Benavidez, 2018).

In summary, including the $P$ factor in (R)USLE applications is important because of the significant effects that some management practices can have on reducing soil loss compared to conventional tillage. The $P$ factor is useful for studies where different management practices are being considered for the same site as it can elucidate which practices are more beneficial for soil conservation.

\section{Limitations of (R)USLE}

This section presents a few of the key limitations of the (R)USLE: regional applicability, uncertainties associated with the model, input data and validation, and representing other types of erosion.

The most commonly cited limitation of the (R)USLE models is their reduced applicability to regions outside of the United States of America (Aksoy and Kavvas, 2005; Naipal et al., 2015; Sadeghi et al., 2014). The original USLE was formulated based on soil erosion studies on agricultural land in the USA. When applied to different climate regimes and land cover conditions, this may lead to greater uncertainties associated with estimates of average annual soil loss (Kinnell, 2010). Since the (R)USLE parameters were developed based on small-scale studies of agricultural plots, there are also uncertainties associated with upscaling the original USLE to the catchment or regional scale (Nagle et al., 1999; Naipal et al., 2015). Wischmeier and Smith (1987) have also warned that using the (R)USLE in conditions extremely different from the agricultural conditions the model was formulated under may lead to extrapolation error. Of the studies reviewed for this paper (Table A1), most applications were done on catchments with predominantly agricultural land use, but under a range of different climatic conditions.

Sensitivity analysis and testing which (R)USLE subfactors suit particular study sites is one method of addressing the (R)USLE's regional applicability. Like the Mangatarere application method in Sect. 2.1, other studies have tested multiple $R$-factor equations on the same dataset to determine which equation was most appropriate for their study site (Eiumnoh, 2000; Benavidez, 2018). Their derived $R$-factor values were compared to the values for catchments with similar climate and rainfall, or to maps of the $R$ factor at larger spatial scales (Panagos et al., 2017). To reduce uncertainty in accounting for land use, work by Post and Hartcher (2005) recommended using $C$-factor values for specific land cover classifications (e.g. specific crops, forest growth stages) instead of values for broad land cover categories (e.g. agriculture, forest). Although $C$-factor values can be taken from the literature or determined in situ, an extensive literature review compiling potential soil loss rates of different crop and forest covers compared to likely soil loss rates of bare soil can be used to determine likely $C$-factor values of a particular site. Improvements and modifications to the (R)USLE subfactors have made it applicable to larger spatial scales, including a coarse-resolution representation at the global scale (Naipal et al., 2015). The pan-European application by Panagos et al. (2015a) showed setting a maximum value for slope steepness of $50 \%\left(26.6^{\circ}\right)$ would prevent significantly large $L S$-factor values and account for the absence of soil on such steep slopes. Assembling published estimates of (R)USLE sub-factors from different climatic regions and soil types would help in sensitivity testing (R)USLE equations, deciding the most appropriate equation to use, and verifying the derived (R)USLE sub-factor values.

The uncertainties associated with the (R)USLE, and arguably soil erosion modelling in general, stem from several factors: the inability of models to capture the complex interactions involved in soil loss, the low availability of longterm reliable data for modelling, and the lack of soil erosion observational data for model validation, especially in datascarce environments. The simplicity of the (R)USLE allows usage in locations where there are insufficient data for more complex models that require large input datasets (de Vente and Poesen, 2005; Hernandez et al., 2012). Of the studies reviewed, very few critically discuss the uncertainties associated with the (R)USLE, but those that do offer several ways to overcome these uncertainties.

Since the (R)USLE does not account for all the complex interactions associated with soil erosion, its predicted soil 
Table 11. $P$ factors for different types of agricultural management practices.

\begin{tabular}{|c|c|c|c|c|}
\hline \multicolumn{5}{|c|}{ David (1988) } \\
\hline Tillage and residue management & $P$ factor & & & \\
\hline Conventional tillage & 1.00 & & & \\
\hline Zoned tillage & 0.25 & & & \\
\hline Mulch tillage & 0.26 & & & \\
\hline Minimum tillage & 0.52 & & & \\
\hline \multirow[t]{2}{*}{ Slope $(\%)$} & Terracing & & Contouring & $\begin{array}{r}\text { Contour strip } \\
\text { cropping }\end{array}$ \\
\hline & Bench & Broad-based & & \\
\hline $1-2$ & 0.10 & 0.12 & 0.60 & 0.30 \\
\hline $3-8$ & 0.10 & 0.10 & 0.50 & 0.15 \\
\hline $9-12$ & 0.10 & 0.12 & 0.60 & 0.30 \\
\hline $13-16$ & 0.10 & 0.14 & 0.70 & 0.35 \\
\hline $17-20$ & 0.12 & 0.16 & 0.80 & 0.40 \\
\hline $21-25$ & 0.12 & 0.18 & 0.90 & 0.45 \\
\hline$>25$ & 0.14 & 0.20 & 0.95 & 0.50 \\
\hline \multicolumn{5}{|c|}{ Panagos et al. (2015c) } \\
\hline Slope $(\%)$ & Contouring $P$ factor & & & \\
\hline $9-12$ & 0.6 & & & \\
\hline $13-16$ & 0.7 & & & \\
\hline 17-20 & 0.8 & & & \\
\hline $21-25$ & 0.9 & & & \\
\hline$>25$ & 0.95 & & & \\
\hline
\end{tabular}

erosion rates should be taken as best estimates rather than absolute values (Wischmeier and Smith, 1987). Some applications have chosen to display their soil loss results as categorical to produce maps that show low, medium, or high areas of vulnerability instead of showing annual average amounts (Adornado et al., 2009; Schmitt, 2009). The (R)USLE is a good first attempt at identifying vulnerable areas and estimating soil loss for a landscape at the baseline scenario due to the model's relative simplicity and few data requirements (Aksoy and Kavvas, 2005). The (R)USLE is also useful for doing scenario analysis to check whether changing land use or management practices would either exacerbate or mitigate soil loss, making it useful for comparison purposes (Merritt et al., 2004; Nigel and Rughooputh, 2012).

Validating the soil erosion rates produced by the (R)USLE is difficult because of the lack of easily obtainable observational soil erosion records, especially in data-scarce environments. Out of the (R)USLE applications reviewed for this paper, $\sim 30 \%$ presented explicit comparisons between their modelled soil loss from (R)USLE and observed soil loss, modelled soil loss from (R)USLE and other models (one study), and soil loss from multiple models and observed soil loss (one study).

One study compared the soil loss rates predicted by the RUSLE to estimates of the physically based WEPP (Water
Erosion Prediction Project) model. Amore et al. (2004) compared RUSLE and WEPP and found that the ratio of modelled to observed soil loss of WEPP (0.7) was better than RUSLE (0.2) for the Trinità basin. However, both RUSLE and WEPP over-predicted sediment yield by up to 5 times the observed value for the nearby Ragoleto basin (Amore et al., 2004). Although WEPP also estimates rill and interrill erosion, WEPP is a continuous daily model that accounts for deposition and sediment delivery, which RUSLE does not predict (Aksoy and Kavvas, 2005).

Another study compared the soil loss estimates of the RUSLE and Unit Stream Power Erosion Deposition Model (USPED) to each other, and to observed data. In a comparison between the RUSLE and USPED, the ratio of modelled to observed of soil loss was almost unity for the USPED but 0.86 for the RUSLE (Aiello et al., 2014). The USPED model builds and improves on the RUSLE sub-factors through its ability to incorporate overland flow and sediment transport through the landscape (Aiello et al., 2014; Zakerinejad and Maerker, 2015).

Based on the remaining studies that reported comparisons of modelled RUSLE soil loss to observed soil loss, the modelled-to-observed ratio ranged from extreme underprediction at 0.04 to over-prediction at over 3 times the observed values. The applications where RUSLE severely 
under-predicted soil loss cited the model's inability to account for gully erosion and mass wasting as one of the reasons for estimation errors, thus underscoring the importance of including these types of erosion in future improvements to RUSLE (Dabney et al., 2012; Gaubi et al., 2017). Another issue is differences in temporal and/or spatial resolution and sometimes differing timescales between modelled and observed estimates. Average observations based on occasional grab samples of sediment in streams may not well represent the monthly to annual sediment loads the (R)USLE is attempting to estimate. In another example, López-Vicente et al. (2008) compared observed to modelled values and had a ratio of modelled to observed soil loss of 0.62 . However, the "observed" soil loss was based on ${ }^{137} \mathrm{Cs}$ measurements that were indicative of average soil loss values for the past 40 years, while the model values were based on 1997-2006 driving data. During this period, the study area experienced lower precipitation and thus had lower modelled soil loss measurements compared to the soil loss derived from the ${ }^{137}$ Cs records (López-Vicente et al., 2008).

As stated earlier, the regional applicability of the RUSLE is a limitation that requires the sub-factors to be adjusted and modified based on the specific characteristics of the researcher's study site. Nakil and Khire (2016) and Abu Hammad et al. (2005) show this important practice in RUSLE applications in their studies. Through testing and refining their method of accounting for topography through the $L S$ factor, the ratio of modelled to observed soil loss ranged from 0.8 to almost unity (Nakil and Khire, 2016). The initial application of RUSLE of Abu Hammad et al. (2005) over-estimated soil loss by a factor of 3, but with adjustments to the subfactors based on local data on soil moisture, land cover, and support practices, the model error was reduced to $14 \%$. The importance of adjusting RUSLE with the availability of more detailed data was further shown in the pan-European study of Panagos et al. (2015e), where detailed soil, topography, land cover, and management practices allowed the researchers to refine their application where most of the ratios of modelled to observed soil loss were very good (0.9 to 1.3$)$. In the validation areas where the soil loss comparisons were not good, further local testing and refining of the RUSLE subfactors is seen as an area in which to improve the model results (Beskow et al., 2009; Ozsoy et al., 2012; Panagos et al., 2015e).

A global soil erosion study using RUSLE was accomplished by Borrelli et al. (2017) using the rainfall erosivity map generated by Panagos et al. (2017) that showed comparable results to regional and local soil erosion estimates, and good agreement with global soil erosion datasets such as the Global Assessment of Human-induced Soil Degradation (GLASOD) dataset ${ }^{4}$.

\footnotetext{
${ }^{4}$ https://www.isric.online/projects/ global-assessment-human-induced-soil-degradation-glasod (last access: 12 November 2018)

Future work in the soil erosion literature could include assembling a comprehensive database of global, regional, and national soil erosion rates to allow comparison between soil erosion modelling methods, not just (R)USLE results. A proxy for understanding soil erosion is water quality data such as total suspended solids (TSS) that includes sediment delivery and organic sources (Schmitt, 2009; Russo, 2015). However, TSS usually excludes the larger and heavier bedload sediments that could be resulting from mass wasting events or erosion (Nagle et al., 1999). Nevertheless, water quality data are useful for inferring likely temporal patterns of soil erosion or the sediment yield during seasons of heavy rainfall or after extreme events. Ground truthing or analysis of satellite imagery is another useful method of validating the (R)USLE results, as the areas of extreme erosion risk can be checked for physical evidence of soil loss occurrence (De Asis and Omasa, 2007; Adornado and Yoshida, 2010; Nontananandh and Changnoi, 2012). The soil loss estimates can be validated against observations from similar catchments, recorded events of mass wasting, or larger-scale soil loss studies at the national or regional scale (Životić et al., 2012; Panagos et al., 2015e; Nakil and Khire, 2016).

Lastly, a frequently cited limitation is that the (R)USLE estimates soil loss through sheet and rill erosion, but not from other types of erosion such as gully erosion, channel erosion, bank erosion, or mass wasting events such as landslides (Nagle et al., 1999; Wischmeier and Smith, 1978). By excluding these types of erosion, the (R)USLE may underestimate the actual soil loss (Thorne et al., 1985). The model also does not account for deposition, leading to overestimation, or sediment routing (Desmet and Govers, 1996; Wischmeier and Smith, 1978). Since it does not predict the sediment pathways from hill slopes to water bodies, it is difficult to analyse possible effects on downstream areas, such as pollution or sedimentation (Jahun et al., 2015). One of the possible methods for linking the (R)USLE results to sediment delivery to streams is using the sediment delivery ratio (SDR), defined as "the ratio of the sediment delivered at a location in the stream system to the gross erosion from the drainage area above that point" (Yoon et al., 2009). This parameter varies depending on the gradient, slope shape, and length and can also be influenced by land cover, roughness, etc. (Wu et al., 2005). Given that it is influenced by characteristics similar to those of the (R)USLE, future work can include not only combining the (R)USLE with the SDR to estimate sediment delivery to streams but also avoiding possible double counting. These two limitations of deposition and routing are linked to the model's representation of more topographically complex terrain, and previous studies have attempted to address them by improving on the $L S$ factor by incorporating upstream contributing area (Desmet and Govers, 1996; Moore et al., 1991). A more detailed discussion of addressing these limitations is in Sect. 4.1.

Despite these drawbacks, the USLE family of models is still widely used because of is relative simplicity and low 
data requirements compared to more complex physically based models. Studies around the world continue to improve (R)USLE parameterisation and application in different climate regimes and locations.

\section{Future directions}

Since the (R)USLE and its family of models are used over different geographic locations and climate types, it is important for future research to build on them and improve their representation of real-world soil loss. Some of the future directions include incorporating soil loss from other types of erosion, estimating soil loss at seasonal or sub-annual temporal scales, and improving the consistency of formulae and units in the scientific literature.

\subsection{Representing other types of erosion}

As previously discussed in Sect. 3, the (R)USLE does not account for all erosion types. This section mostly discusses possible extensions to include gully erosion, but further work to incorporate channel/bank erosion and mass wasting events must also be done.

The inability of (R)USLE to account for soil losses due to ephemeral gullies can lead to under-prediction of soil loss estimates (Thorne et al., 1985). These ephemeral gullies are small channels that form due to the erosive action of overland flow during a rainfall event (Momm et al., 2012). Gully erosion can contribute a significant amount of sediment loss; for example gully erosion is estimated to contribute between $30 \%$ and $50 \%$ of soil loss from a range of catchments in New Zealand (Basher et al., 2012). Desmet and Govers (1996) recommended that delineation of ephemeral gullies, such as through the Compound Topographic Index (CTI) developed by Thorne et al. (1985), combined with (R)USLE could improve the identification of vulnerable areas within a watershed. The CTI of Thorne et al. (1985) uses topographic analysis to predict locations and soil loss rates of ephemeral gullies based on upstream drainage area, slope, and the planform curvature. Hence, the combination of CTI and the (R)USLE is a promising direction for including gully erosion, but care must be taken in coupling these models because both already account for upstream drainage area and slope. Simply adding their soil loss rates could lead to "double counting" and requires further research to determine the threshold values of CTI and $L S$ factor over which ephemeral gullying is likely (Benavidez, 2018).

Work along these lines, combining the effect of rill and sheet erosion with gully erosion was done by Momm et al. (2012) in Kansas and by Zakerinejad and Maeker (2015) in the Mazayjan watershed in Iran. Momm et al. (2012) combined several types of erosion - sheet and rill, gully, and bed and bank erosion - with the sheet and rill erosion estimated using the (R)USLE model. They used varying criti- cal CTI thresholds to iteratively generate potential locations of ephemeral gullies and identify sub-watersheds prone to gully erosion, and then used scenario analysis to estimate reductions in sediment yields under conservation practices (Momm et al., 2012). One of the limitations of the Momm et al. (2012) study was that they only had a coarse-resolution DEM. Since ephemeral gullies are small features (typically a few metres wide and $\sim 25 \mathrm{~cm}$ deep), higher-resolution DEMs such as those derived from lidar data would be better for analysis of these topographic features. The USPED, which is similar to the (R)USLE model, has also been used to estimate rill and sheet erosion rates with a stream power index (SPI) approach to estimate gully erosion rates (Zakerinejad and Maerker, 2015). Zakerinejad and Maerker (2015) estimated gully erosion in metric tons per hectare per year and combined it with the estimates from the USPED model to produce a map showing potential erosion and deposition within their study area. Hence, there are precedents as well as a need to combine erosion estimates from (R)USLE with a procedure that accounts for gully erosion for more effective land management.

\subsection{Seasonal erosion vulnerability}

(R)USLE applications usually estimate soil loss at the annual timescale, and the MUSLE estimates soil loss from a single storm event (Renard et al., 1997; Sadeghi et al., 2014). As seen in the review of methods of calculating rainfall erosivity, many different studies have attempted to estimate the $R$ factor, underscoring its importance to soil erosion research. However, estimating the $R$ factor at the annual timescale does not account for seasonal variations in rainfall. It is useful for land management to understand seasonal variations in soil erosion vulnerability because of the dual effect of rainfall and land cover on soil loss, and the effect of rainfall on land cover (Kulikov et al., 2016). For example, when a season of heavy rainfall coincides with low vegetation cover, the risk of soil erosion increases considerably (Ferreira and Panagopoulos, 2014). Thus, most of the studies around seasonal estimations of soil loss revolve around changes in land cover and rainfall. The soil erodibility ( $K$ factor) can vary too due to changes in permeability and the effects of freezing and thawing, but it is less frequently studied compared to variations in land cover and rainfall (López-Vicente et al., 2008).

Studies that incorporate seasonality in the (R)USLE commonly compute $R$ factors and $C$ factors at monthly or seasonal timescales. Lu and Yu (2002) computed monthly $R$ factors in Australia, which were then used in a later study that computed $C$ factors based on satellite imagery and the NDVI, to produce monthly maps of soil erosion vulnerability over the entire Australian continent (Lu et al., 2003; Lu and Yu, 2002). The method of estimating $C$ factors using NDVI is popular due to the availability of remotely sensed imagery and the capability of processing datasets with relative expe- 
dience compared to time-consuming fieldwork. Other studies have used the NDVI and similar characteristics to estimate monthly and seasonal $C$ factors in Brazil, Greece, and Kyrgyzstan (Alexandridis et al., 2015; Durigon et al., 2014; Ferreira and Panagopoulos, 2014; Kulikov et al., 2016; Panagos et al., 2012). The $C$ factors can also be estimated monthly through the method recommended by (R)USLE, but this requires knowledge of prior land use, canopy cover, surface roughness, and soil moisture (López-Vicente et al., 2008).

Monthly or seasonal estimations of rainfall factors are more useful to land management planning around crop growth cycles and tillage practices (Diodato, 2004). Studies have used different methods to calculate $R$ factors, with data requirements ranging from per-storm basis to annual averages. To estimate monthly and seasonal estimations, the required rainfall data can be as fine as individual storm intensity to use the (R)USLE method or be as coarse as average monthly rainfall. Diodato (2004) in Italy and Kavian et al. (2011) used the (R)USLE method to calculate storm energy and summed these up per month and season to obtain $R$ factors. Other studies have used daily and monthly rainfall to calculate monthly $R$ factors and combine them for seasonal $R$ factors (Alexandridis et al., 2015; Kavian et al., 2011; López-Vicente et al., 2008; Lu et al., 2003; Panagos et al., 2015d; Shamshad et al., 2008). The results of these studies focused on identifying high and low periods of the landscape's vulnerability to soil erosion, depending on combinations of rainfall intensity and land cover.

To summarise, modelling the sub-annual variations of soil erosion and sediment yield is important because of the many temporal and spatial variations in the factors that influence annual soil loss. These variations include seasonal rainfall variability, changes in the spatial distribution of erosionprone areas over crop growth and tillage cycles, and potential seasonal changes in water quality due to changes in seasonable distributions of extreme rainfall events. Seasons with higher heavy rainfall will have a higher possibility of soil loss and mass wasting events, which in turn have a degrading effect on water quality and can cause destruction of infrastructure, putting communities and lives in danger. Over the crop growth and tillage cycles, the potential sediment yields to streams will change, and this has implications for land management and farmers who must abide by water quality standards. Modelling at the annual timescale is insufficient to capture these seasonal or monthly changes in potential soil loss, which are more important to land management planning, and thus underscores the utility of doing modelling at the sub-annual scale. These sub-annual model results can then be aggregated into an annual estimate of soil loss that would be more accurate compared to modelling using only annual averages of rainfall or land cover conditions.

\subsection{Consistency in units}

The USLE was originally developed using imperial units; although the handbook provides conversion factors to convert to metric, there are still issues within the scientific literature regarding units. In the process of this review, it was noted that, although most studies used the metric units for $R$ factor and $K$ factor, there were other studies that did not report their units or had units that were not the imperial or metric units of (R)USLE. Since the original (R)USLE was formulated with US customary units, researchers must be careful to use the correct units and conversions to metric (Renard and Freimund, 1994). To convert from imperial to metric units, Renard et al. (1997) recommends a conversion factor of 17.02 for the $R$ factor and 0.1317 for the $K$ factor. As mentioned in Sect. 3, there are uncertainties associated with the (R)USLE, and publishing sub-factor values and soil loss estimates for future reference by other researchers is a potential way of reducing some of those uncertainties. The problem of unclear or inconsistent units causes problems for future researchers in terms of adapting the rainfall erosivity or soil erodibility equations for their own study sites, underscoring the need for clear and explicit reporting of units in the (R)USLE literature.

\section{Summary and conclusion}

At first glance, the USLE, along with its family of models, seem like a relatively straightforward linear model. However, this review shows the difficulty in finding the most appropriate method of calculating its sub-factors depending on location, availability of data, and previous studies done in nearby or similar regions. This paper reviewed the different components of the Universal Soil Loss Equation (USLE) and its updated form, the Revised Universal Soil Loss Equation (RUSLE). Different studies around the world were collected and analysed to compile how they adapted (R)USLE to their unique conditions, how they had estimated the (R)USLE subfactors with limited data availability, and how these methods have been used by subsequent soil erosion studies. At the end of each sub-factor section, a brief summary is given outlining which datasets and equations would be useful for new users depending on their location and data availability. Each sub-factor section clarifies some of the assumptions and limitations associated with the original (R)USLE models and how users can overcome some of the uncertainties associated with these sub-factors. One common theme in the sub-factor reviews is that sensitivity testing of the sub-factors should be done by future (R)USLE applications by trialling several equations for one sub-factor before using it in the final soil erosion estimates.

This paper also presented the limitations of the (R)USLE, mainly the uncertainties associated with the simple empirical model, uncertainties with data availability and validation, 
and the model's inability to account for types of soil erosion other than rill or inter-rill erosion. Lastly, the paper outlined some key future directions for (R)USLE research: incorporating soil loss from other types of soil erosion, importance of estimating soil loss at sub-annual scales and recommended equations, validation of soil loss estimates, and consistency in reporting units in the future literature. To represent gully erosion, the Compound Topographic Index (CTI) was briefly discussed, while the sediment delivery ratio (SDR) was also presented to account for linking soil loss to sediment delivery to streams. The ability to predict sub-annual soil loss or seasonal erosion modelling is important in study areas having high temporal variation of rainfall throughout the year, and/or having varying crop growth and tillage cycles, both being factors that can impact potential soil loss. Land management policy and decisions might be more robust if they consider modelling scenarios that test the effect of different types of crop and support practices on soil erosion mitigation. These scenarios can include a myriad of options: expanded urban areas or development, changing crop rotation cycles, or applying support practices in steep or upland areas. Further, seasonal soil erosion has implications on water quality, and understanding the extent of the problem can help local government address potential sources of sediment delivery and be more proactive in land management. Validation of soil loss estimates is important in understanding the accuracy of the (R)USLE application, and future work could involve compiling an extensive global database of soil loss estimates derived from observations and models, including those models more complex than (R)USLE. This database would be useful for future researchers in comparing their results and assess the accuracy of model applications. Greater transparency in reporting the sub-factor units, sub-factor values, and soil loss estimates is important to decrease uncertainty when future (R)USLE applications borrow sub-factor equations and values from previous studies. The limitations section addresses the fourth objective of this review.

In conclusion, the choices made regarding applications of the (R)USLE depend on the kind of data that are available for a study area and how they can adapt or change information from other studies to suit their area's particular climate, soil type, topography, typical land cover, and support practices.
Data availability. The datasets mentioned in this review are available for download after registration or through contacting the authors. The following datasets were retrieved from the Joint Research Centre European Soil Data Centre (ESDAC): global rainfall erosivity (accessible at https://esdac.jrc.ec.europa.eu/content/global-rainfall-erosivity; Panagos et al., 2017) and rainfall erosivity in the EU and Switzerland (accessible at https://esdac.jrc.ec.europa.eu/content/ rainfall-erosivity-european-union-and-switzerland; Panagos et al., 2015d). The rainfall erosivity map for Brazil was constructed by da Silva (2004). The MODIS normalized difference vegetation index (NDVI) is accessible at http://glcf.umd.edu/data/ndvi/ (Caroll et al., 2004). The global-scale NDVI dataset generated by NASA is accessible at https://data.giss.nasa.gov/landuse/ndvi.html (NASA, 2018). The Global Assessment of Human-induced Soil Degradation (GLASOD) is accessible at http://data.isric.org/ geonetwork/srv/eng/catalog.search \T1\textbackslash\#/metadata/ 9e84c15e-cb46-45e2-9126-1ca38bd5cd22 (Bridges and Oldeman, 1999). 


\section{Appendix A}

Table A1. Summary of previous studies that have applied the USLE and RUSLE.

\begin{tabular}{|c|c|c|c|c|c|c|}
\hline Author & Location & $R$ factor & $K$ factor & $L S$ factor & $C$ factor & $P$ factor \\
\hline David (1988) & $\begin{array}{l}\text { Various water- } \\
\text { sheds in the } \\
\text { Philippines }\end{array}$ & $\begin{array}{l}\text { Mihara (1951) } \\
\text { and Hudson } \\
\text { (1971) as cited } \\
\text { in David (1988) }\end{array}$ & $\begin{array}{l}\text { Wischmeier } \\
\text { and Mannering } \\
(1969)\end{array}$ & $\begin{array}{l}\text { Madarcos } \\
\text { (1985) and } \\
\text { Smith and } \\
\text { Whitt (1947) }\end{array}$ & Literature & Literature \\
\hline $\begin{array}{l}\text { Eiumnoh } \\
(2000)\end{array}$ & $\begin{array}{l}\text { Sakae Krang } \\
\text { watershed } \\
\text { (Thailand) }\end{array}$ & $\begin{array}{l}\text { El-Swaify et } \\
\text { al. (1987) as } \\
\text { cited in Merritt } \\
\text { et al. (2004) }\end{array}$ & USLE method & USLE method & Literature & $\begin{array}{l}\text { None observed } \\
(P=1)\end{array}$ \\
\hline $\begin{array}{l}\text { Fernandez et } \\
\text { al. }(2003)\end{array}$ & $\begin{array}{l}\text { Lawyers Creek } \\
\text { watershed } \\
\text { (USA) }\end{array}$ & $\begin{array}{l}\text { USDA-ARS } \\
(2002)\end{array}$ & $\begin{array}{l}\text { From the } \\
\text { SSURGO } \\
\text { database } \\
\text { (USDA) }\end{array}$ & $\begin{array}{l}\text { Upslope con- } \\
\text { tributing area } \\
\text { method }\end{array}$ & $\begin{array}{l}\text { Database from } \\
\text { RUSLE } \\
\text { software }\end{array}$ & $\begin{array}{l}\text { Database from } \\
\text { RUSLE } \\
\text { software }\end{array}$ \\
\hline $\begin{array}{l}\text { Merritt et } \\
\text { al. (2004) }\end{array}$ & $\begin{array}{l}\text { Mae Chem } \\
\text { watershed } \\
\text { (Thailand) }\end{array}$ & $\begin{array}{l}\text { El-Swaify et } \\
\text { al. (1987) as } \\
\text { cited in Merritt } \\
\text { et al. (2004) }\end{array}$ & $\begin{array}{l}\text { Previous stud- } \\
\text { ies in area }\end{array}$ & USLE method & $\begin{array}{l}\text { Previous stud- } \\
\text { ies in area }\end{array}$ & $\begin{array}{l}\text { Previous stud- } \\
\text { ies in area }\end{array}$ \\
\hline $\begin{array}{l}\text { Post and } \\
\text { Hartcher } \\
(2005)\end{array}$ & $\begin{array}{l}\text { Mae Chem } \\
\text { watershed } \\
\text { (Thailand) }\end{array}$ & $\begin{array}{l}\text { El-Swaify et } \\
\text { al. (1987) as } \\
\text { cited in Merritt } \\
\text { et al. (2004) }\end{array}$ & $\begin{array}{l}\text { Previous stud- } \\
\text { ies in area }\end{array}$ & $\begin{array}{l}L=1 \\
S=: \text { derived } \\
\text { from DEM }\end{array}$ & $\begin{array}{l}\text { Previous stud- } \\
\text { ies in area }\end{array}$ & $\begin{array}{l}\text { None observed } \\
(P=1)\end{array}$ \\
\hline $\begin{array}{l}\text { Dumas and } \\
\text { Fossey (2009) }\end{array}$ & $\begin{array}{l}\text { Efate Island } \\
\text { (Vanuatu) }\end{array}$ & $\begin{array}{l}\text { Roose (1975) } \\
\text { and Morgan } \\
\text { (1974) as cited } \\
\text { in Morgan } \\
(2005)\end{array}$ & USLE method & $\begin{array}{l}\text { RUSLE method } \\
\text { at pixel level }\end{array}$ & Literature & $\begin{array}{l}\text { None observed } \\
(P=1)\end{array}$ \\
\hline $\begin{array}{l}\text { Adornado et } \\
\text { al. (2009) }\end{array}$ & $\begin{array}{l}\text { REINA (Philip- } \\
\text { pines) }\end{array}$ & $\begin{array}{l}\text { El-Swaify et } \\
\text { al. (1987) as } \\
\text { cited in Merritt } \\
\text { et al. (2004) }\end{array}$ & $\begin{array}{l}\text { Table by Stew- } \\
\text { art et al. (1975) }\end{array}$ & $\begin{array}{l}\text { Upslope con- } \\
\text { tributing area } \\
\text { method }\end{array}$ & Literature & $\begin{array}{l}\text { None observed } \\
(P=1)\end{array}$ \\
\hline Schmitt (2009) & $\begin{array}{l}\text { Negros Island } \\
\text { (Philippines) }\end{array}$ & RUSLE method & USLE method & $\begin{array}{l}\text { RUSLE method } \\
\text { at pixel level }\end{array}$ & Literature & $\begin{array}{l}\text { Previous stud- } \\
\text { ies }\end{array}$ \\
\hline $\begin{array}{l}\text { Jayasinghe et } \\
\text { al. (2010) }\end{array}$ & $\begin{array}{l}\text { Nuwaraeliya } \\
\text { (Sri Lanka) }\end{array}$ & $\begin{array}{l}\text { El-Swaify et } \\
\text { al. (1987) as } \\
\text { cited in Merritt } \\
\text { et al. (2004) }\end{array}$ & $\begin{array}{l}\text { Table by Stew- } \\
\text { art et al. (1975) }\end{array}$ & $\begin{array}{l}\text { Upslope con- } \\
\text { tributing area } \\
\text { method }\end{array}$ & Literature & $\begin{array}{l}\text { None observed } \\
(P=1)\end{array}$ \\
\hline $\begin{array}{l}\text { Jain and Das } \\
(2010)\end{array}$ & $\begin{array}{l}\text { Jharkhand } \\
\text { (India) }\end{array}$ & $\begin{array}{l}\text { Ram et } \\
\text { al. (2004) } \\
\text { as cited in Jain } \\
\text { and Das (2010) }\end{array}$ & $\begin{array}{l}\text { USLE method } \\
\text { and previous } \\
\text { studies }\end{array}$ & $\begin{array}{l}\text { Upslope con- } \\
\text { tributing area } \\
\text { method }\end{array}$ & Literature & $\begin{array}{l}\text { None observed } \\
(P=1)\end{array}$ \\
\hline $\begin{array}{l}\text { Adornado and } \\
\text { Yoshida (2010) }\end{array}$ & $\begin{array}{l}\text { Bukidnon } \\
\text { (Philippines) } \\
\text { and also } \\
\text { REINA (Philip- } \\
\text { pines) }\end{array}$ & $\begin{array}{l}\text { El-Swaify et } \\
\text { al. (1987) as } \\
\text { cited in Merritt } \\
\text { et al. (2004) }\end{array}$ & $\begin{array}{l}\text { Table by Stew- } \\
\text { art et al. (1975) }\end{array}$ & $\begin{array}{l}\text { Upslope con- } \\
\text { tributing area } \\
\text { method }\end{array}$ & Literature & $\begin{array}{l}\text { None observed } \\
(P=1)\end{array}$ \\
\hline
\end{tabular}


Table A1. Continued.

\begin{tabular}{|c|c|c|c|c|c|c|}
\hline Author & Location & $R$ factor & $K$ factor & $L S$ factor & $C$ factor & $P$ factor \\
\hline $\begin{array}{l}\text { Boyle et } \\
\text { al. (2011) }\end{array}$ & $\begin{array}{l}\text { California } \\
\text { (USA) }\end{array}$ & $\begin{array}{l}\text { From previous } \\
\text { studies }\end{array}$ & $\begin{array}{l}\text { From previous } \\
\text { studies }\end{array}$ & $\begin{array}{l}\text { Upslope con- } \\
\text { tributing area } \\
\text { method }\end{array}$ & Literature & $\mathrm{n} / \mathrm{a}$ \\
\hline $\begin{array}{l}\text { Chen et } \\
\text { al. (2011) }\end{array}$ & $\begin{array}{l}\text { Xiangxi water- } \\
\text { shed (China) }\end{array}$ & $\begin{array}{l}\text { Wischmeier } \\
\text { and Smith } \\
(1978)\end{array}$ & $\begin{array}{l}\text { Williams and } \\
\text { Renard (1983) } \\
\text { nomograph }\end{array}$ & $\begin{array}{l}\text { Upslope con- } \\
\text { tributing area } \\
\text { method }\end{array}$ & Using NDVI & $\mathrm{n} / \mathrm{a}$ \\
\hline $\begin{array}{l}\text { Demirci and } \\
\text { Karaburun } \\
(2012)\end{array}$ & $\begin{array}{l}\text { Büyükçekmece } \\
\text { Lake watershed } \\
\text { (Turkey) }\end{array}$ & $\begin{array}{l}\text { Arnoldus } \\
(1980)\end{array}$ & $\begin{array}{l}\text { Torri et } \\
\text { al. (1997) equa- } \\
\text { tion }\end{array}$ & $\begin{array}{l}\text { Upslope con- } \\
\text { tributing area } \\
\text { method }\end{array}$ & Using NDVI & $\begin{array}{l}\text { None observed } \\
(P=1)\end{array}$ \\
\hline $\begin{array}{l}\text { Nontananandh } \\
\text { and Changnoi } \\
(2012)\end{array}$ & $\begin{array}{l}\text { Songkhram } \\
\text { watershed } \\
\text { (Thailand) }\end{array}$ & $\begin{array}{l}\text { Land } \\
\text { Development } \\
\text { Department } \\
\text { (2000) }\end{array}$ & $\begin{array}{l}\text { Values from } \\
\text { Land } \\
\text { Development } \\
\text { Department } \\
(2000)\end{array}$ & $\begin{array}{l}\text { Modified } \\
\text { RUSLE method }\end{array}$ & Literature & $\begin{array}{l}\text { None observed } \\
(P=1)\end{array}$ \\
\hline $\begin{array}{l}\text { Ozsoy et } \\
\text { al. (2012) }\end{array}$ & $\begin{array}{l}\text { Mustafakemalpaşa } \\
\text { River basin } \\
\text { (Turkey) }\end{array}$ & $\begin{array}{l}\text { From previous } \\
\text { studies }\end{array}$ & USLE method & $\begin{array}{l}\text { RUSLE } \\
\text { method, } \\
\text { using a third- } \\
\text { party pro- } \\
\text { gramme }\end{array}$ & Literature & $\begin{array}{l}\text { None observed } \\
(P=1)\end{array}$ \\
\hline $\begin{array}{l}\text { Delgado and } \\
\text { Canters (2012) }\end{array}$ & $\begin{array}{l}\text { Claveria } \\
\text { (Philippines) }\end{array}$ & $\begin{array}{l}\text { Shamshad et } \\
\text { al. (2008) }\end{array}$ & USLE method & $\begin{array}{l}\text { RUSLE2 pro- } \\
\text { gramme, using } \\
\text { the upslope } \\
\text { contributing } \\
\text { area method }\end{array}$ & Literature & David (1988) \\
\hline $\begin{array}{l}\text { Hernandez et } \\
\text { al. (2012; using } \\
\text { SedNet, which } \\
\text { has an USLE } \\
\text { component) }\end{array}$ & $\begin{array}{l}\text { Pagsanjan } \\
\text { (Philippines) }\end{array}$ & $\begin{array}{l}\text { El-Swaify et } \\
\text { al. (1987) as } \\
\text { cited in Merritt } \\
\text { et al. (2004) }\end{array}$ & $\begin{array}{l}\text { Wischmeier } \\
\text { and Mannering } \\
\text { (1969) }\end{array}$ & $\begin{array}{l}\text { Algorithm } \\
\text { within SedNet }\end{array}$ & Literature & $\mathrm{n} / \mathrm{a}$ \\
\hline $\begin{array}{l}\text { Sinha and Joshi } \\
\text { (2012) }\end{array}$ & $\begin{array}{l}\text { Maharashtra } \\
\text { (India) }\end{array}$ & Roose (1975) & USLE method & Morgan (1986) & Literature & Literature \\
\hline $\begin{array}{l}\text { Nigel and } \\
\text { Rughooputh } \\
(2012)\end{array}$ & Mauritius & $\begin{array}{l}\text { Arnoldus } \\
\text { (1980) as cited } \\
\text { in Le Roux et } \\
\text { al. (2005) }\end{array}$ & $\begin{array}{l}\text { From previous } \\
\text { studies }\end{array}$ & $\begin{array}{l}\text { Upslope con- } \\
\text { tributing area } \\
\text { method }\end{array}$ & Literature & Literature \\
\hline $\begin{array}{l}\text { Životić et } \\
\text { al. (2012) }\end{array}$ & $\begin{array}{l}\text { Nišava River } \\
\text { basin (Serbia) }\end{array}$ & $\begin{array}{l}\text { Wischmeier } \\
\text { and Smith } \\
(1978)\end{array}$ & USLE method & RUSLE method & Using NDVI & $\begin{array}{l}\text { None observed } \\
(P=1)\end{array}$ \\
\hline $\begin{array}{l}\text { Rozos et } \\
\text { al. (2013) }\end{array}$ & $\begin{array}{l}\text { Euboea Island } \\
\text { (Greece) }\end{array}$ & $\begin{array}{l}\text { Flabouris } \\
(2008)\end{array}$ & $\begin{array}{l}\text { Based on geo- } \\
\text { logical charac- } \\
\text { teristics }\end{array}$ & Morgan (1986) & Literature & $\begin{array}{l}\text { None observed } \\
(P=1)\end{array}$ \\
\hline $\begin{array}{l}\text { Bagherzadeh } \\
(2014)\end{array}$ & $\begin{array}{l}\text { Mashhad plain } \\
\text { (Iran) }\end{array}$ & $\begin{array}{l}\text { Wischmeier } \\
\text { and Smith } \\
(1978)\end{array}$ & USLE method & USLE method & & $\begin{array}{l}\text { None observed } \\
(P=1)\end{array}$ \\
\hline
\end{tabular}


Table A1. Continued.

\begin{tabular}{|c|c|c|c|c|c|c|}
\hline Author & Location & $R$ factor & $K$ factor & $L S$ factor & $C$ factor & $P$ factor \\
\hline $\begin{array}{l}\text { Ferreira and } \\
\text { Panagopoulos } \\
(2014)\end{array}$ & $\begin{array}{l}\text { Alqueva } \\
\text { (Portugal) }\end{array}$ & $\begin{array}{l}\text { Similar to } \\
\text { Loureiro and } \\
\text { Coutinho } \\
\text { (2001) }\end{array}$ & USLE method & $\begin{array}{l}\text { Upslope con- } \\
\text { tributing area } \\
\text { method }\end{array}$ & Using NDVI & $\begin{array}{l}\text { None observed } \\
(P=1)\end{array}$ \\
\hline Li et al. (2014) & $\begin{array}{l}\text { Guangdong } \\
\text { (China) }\end{array}$ & $\begin{array}{l}\text { Zhou et } \\
\text { al. (1995) }\end{array}$ & USLE method & $\begin{array}{l}\text { Similar to } \\
\text { RUSLE method }\end{array}$ & Using NDVI & $\begin{array}{l}1 \text { for wasteland } \\
\text { and built-up } \\
\text { area, } \\
0.5 \text { for forest, } \\
0.2 \text { for orchard } \\
\text { land, } \\
0.35 \text { for crop- } \\
\text { land }\end{array}$ \\
\hline $\begin{array}{l}\text { Zakerinejad } \\
\text { and Maerker } \\
\text { (2015; using } \\
\text { USPED, which } \\
\text { has USLE } \\
\text { components) }\end{array}$ & $\begin{array}{l}\text { Mazayjan } \\
\text { (Iran) }\end{array}$ & $\begin{array}{l}\text { Ferro et } \\
\text { al. (1991); } \\
\text { Renard and } \\
\text { Freimund } \\
\text { (1994); } \\
\text { Sadeghifard } \\
\text { et al. (2004) }\end{array}$ & RUSLE method & $\begin{array}{l}\text { Algorithm } \\
\text { within USPED }\end{array}$ & Literature & $\begin{array}{l}\text { None observed } \\
(P=1)\end{array}$ \\
\hline $\begin{array}{l}\text { Jahun et } \\
\text { al. (2015) }\end{array}$ & Crete (Greece) & Fu et al. (2006) & RUSLE method & $\begin{array}{l}\text { Upslope con- } \\
\text { tributing area } \\
\text { method }\end{array}$ & Using NDVI & $\begin{array}{l}\text { Previous } \\
\text { studies }\end{array}$ \\
\hline $\begin{array}{l}\text { Farhan and } \\
\text { Nawaiseh } \\
(2015)\end{array}$ & $\begin{array}{l}\text { Wadi Kerak } \\
\text { catchment (Jor- } \\
\text { dan) }\end{array}$ & $\begin{array}{l}\text { Eltaif et } \\
\text { al. (2010) }\end{array}$ & $\begin{array}{l}\text { Similar to } \\
\text { USLE } \\
\text { nomograph }\end{array}$ & $\begin{array}{l}\text { Upslope con- } \\
\text { tributing area } \\
\text { method }\end{array}$ & Literature & Literature \\
\hline $\begin{array}{l}\text { Panagos et } \\
\text { al. ( } 2015 \mathrm{e}) \text { and } \\
\text { related papers }\end{array}$ & Europe & $\begin{array}{l}\text { Rainfall } \\
\text { Intensity Sum- } \\
\text { marization } \\
\text { Tool (RIST) }\end{array}$ & USLE method & $\begin{array}{l}\text { 3rd-party } \\
\text { programme }\end{array}$ & Literature & Literature \\
\hline Russo (2015) & $\begin{array}{l}\text { Brunei Darus- } \\
\text { salam }\end{array}$ & $\begin{array}{l}\text { Rosewell and } \\
\text { Turner (1992) }\end{array}$ & $\begin{array}{l}\text { Rosewell } \\
\text { (1997) }\end{array}$ & RUSLE method & $\begin{array}{l}\text { Based on } \\
\text { ground covered }\end{array}$ & $\begin{array}{l}\text { None observed } \\
(P=1)\end{array}$ \\
\hline $\begin{array}{l}\text { Nakil and } \\
\text { Khire (2016) }\end{array}$ & $\begin{array}{l}\text { Gangapur } \\
\text { (India) }\end{array}$ & Nakil (2014) & USLE method & RUSLE method & Literature & Literature \\
\hline $\begin{array}{l}\text { Raissouni et } \\
\text { al. (2016) }\end{array}$ & $\begin{array}{l}\text { Smir Dam } \\
\text { (Morocco) }\end{array}$ & $\begin{array}{l}\text { Similar to } \\
\text { Arnoldus } \\
\text { (1980) methods }\end{array}$ & $\begin{array}{l}\text { Merzouk } \\
(1985)\end{array}$ & $\begin{array}{l}\text { Upslope con- } \\
\text { tributing area } \\
\text { method }\end{array}$ & Literature & $\begin{array}{l}\text { None observed } \\
(P=1)\end{array}$ \\
\hline $\begin{array}{l}\text { Fernandez and } \\
\text { Daigneault } \\
\text { (2016) }\end{array}$ & $\begin{array}{l}\text { Waikato } \\
\text { (New Zealand) }\end{array}$ & $\begin{array}{l}\text { Institute of } \\
\text { Water Research } \\
\text { (2015) }\end{array}$ & $\begin{array}{l}\text { Dymond et } \\
\text { al. (2010) }\end{array}$ & $\begin{array}{l}\text { Upslope con- } \\
\text { tributing area } \\
\text { method }\end{array}$ & $\begin{array}{l}\text { Range between } \\
1 \text { (wood vege- } \\
\text { tation) and } 10 \\
\text { (herbaceous } \\
\text { vegetation or } \\
\text { bare ground) }\end{array}$ & \\
\hline $\begin{array}{l}\text { Duarte et } \\
\text { al. (2016) }\end{array}$ & $\begin{array}{l}\text { Montalegre } \\
\text { (Portugal) }\end{array}$ & $\begin{array}{l}\text { Loureiro and } \\
\text { Coutinho } \\
(2001)\end{array}$ & USLE method & USLE method & Literature & Literature \\
\hline $\begin{array}{l}\text { Gaubi et } \\
\text { al. (2017) }\end{array}$ & $\begin{array}{l}\text { Lebna water- } \\
\text { shed (Tunisia) }\end{array}$ & $\begin{array}{l}\text { Rango and } \\
\text { Arnoldus } \\
\text { (1987) }\end{array}$ & USLE method & $\begin{array}{l}\text { Upslope con- } \\
\text { tributing area } \\
\text { method }\end{array}$ & Literature & $\begin{array}{l}\text { None observed } \\
(P=1)\end{array}$ \\
\hline
\end{tabular}

n/a: not applicable 
Author contributions. The manuscript was mainly written by RB. Proofreading, additions to the text, and feedback were accomplished by BJ, DM, and $\mathrm{KN}$.

Competing interests. The authors declare that they have no conflict of interest.

Acknowledgements. Much of the content of this paper was supported by the Victoria University of Wellington Doctoral Scholarship as part of the PhD research of Rubianca Benavidez.

Edited by: Uwe Ehret

Reviewed by: two anonymous referees

\section{References}

Abu Hammad, A., Lundekvam, H., and Børresen, T.: Adaptation of RUSLE in the eastern part of the Mediterranean region, Environ. Manage., 34, 829-841, https://doi.org/10.1007/s00267-0030296-7, 2005.

Adornado, H. A. and Yoshida, M: Assessing the Adverse Impacts of Climate Change: A Case Study in the Philippines, J. Dev. Sus. Agr., 5, 141-146, 2010.

Adornado, H. A., Yoshida, M., and Apolinares, H.: Erosion Vulnerability Assessment in REINA, Quezon Province, Philippines with Raster-based Tool Built within GIS Environment, J. Agric. Res. , 18, 24-31, https://doi.org/10.3173/air.18.24, 2009.

Aksoy, H. and Kavvas, M. L.: A review of hillslope and watershed scale erosion and sediment transport models, Catena, 64, 247271, https://doi.org/10.1016/j.catena.2005.08.008, 2005.

Aiello, A., Adamo, M., and Canora, F.: Modelling SpatiallyDistributed Soil Erosion through Remotely-Sensed Data and GIS, in: Computational Science and Its Applications - ICCSA 2014, edited by: Murgante, B., Misra, S., Rocha, A. M. A. C., Torre, C. M., Rocha, J. G., Falcão, M. I., Taniar, D., Apduhan, B. O., and Gervasi, O., 372-385, Springer, Cham, https://doi.org/10.1007/978-3-319-09147-1_27, 2014.

Alexandridis, T. K., Sotiropoulou, A. M., Bilas, G., Karapetsas, N., and Silleos, N. G.: The Effects of Seasonality in Estimating the $C$-Factor of Soil Erosion Studies, Land Degrad. Develop., 26, 596-603, https://doi.org/10.1002/ldr.2223, 2015.

Amore, E., Modica, C., Nearing, M. A., and Santoro, V. C.: Scale effect in USLE and WEPP application for soil erosion computation from three Sicilian basins, J. Hydrol., 293, 100-114, https://doi.org/10.1016/j.jhydrol.2004.01.018, 2004.

Arnoldus, H. M. J.: Methodology used to determine the maximum potential average annual soil loss due to sheet and rill erosion in Morocco, FAO Soils Bulletin, 34, 39-51, 1977.

Arnoldus, H. M. J.: An approximation of the rainfall factor in the Universal Soil Loss Equation, in: De Boodt, M. and Gabriels, D., Assessment of Erosion, 127-131, Chichester, UK, Wiley, 1980.

Bagherzadeh, A.: Estimation of soil losses by USLE model using GIS at Mashhad plain, Northeast of Iran, Arab. J. Geosci., 7, 211-220, https://doi.org/10.1007/s12517-012-0730-3, 2014.
Bantayan, N. C. and Bishop, I. D.: Linking objective and subjective modelling for landuse decision-making, Landsc. Urban Plan., 43 , 35-48, https://doi.org/10.1016/S0169-2046(98)00101-7, 1998.

Basher, L., Douglas, G., Elliott, S., Hughes, A., Jones, H., McIvor, I., Page, M., Rosser, B., and Tait, A.: Impacts of climate change on erosion and erosion control methods - A critical review (Vol. 4), available at: https://www.mpi.govt.nz/document-vault/4074 (last access: 12 November 2018), 2012.

Benavidez, R. A.: Understanding the effect of changing land use on floods and soil erosion in the Cagayan de Oro catchment, (Unpublished doctoral dissertation), Victoria University of Wellington, New Zealand, 2018.

Beskow, S., Mello, C. R., Norton, L. D., Curi, N., Viola, M. R., and Avanzi, J. C.: Soil erosion prediction in the Grande River Basin, Brazil using distributed modeling, Catena, 79, 49-59, https://doi.org/10.1016/j.catena.2009.05.010, 2009.

Bonilla, C. A. and Vidal, K. L.: Rainfall erosivity in Central Chile, J. Hydrol., 410, 126-133, https://doi.org/10.1016/j.jhydrol.2011.09.022, 2011.

Borrelli, P., Robinson, D. A., Fleischer, L. R., Lugato, E., Ballabio, C., Alewell, C., Meusburger, K., Modugno, S., Schütt, B., Ferro, V., Bagarello, V., Van Oost, K., Montanarella, L., and Panagos, P.: An assessment of the global impact of 21st century land use change on soil erosion, Nat. Commun., 8, 1-13, https://doi.org/10.1038/s41467-017-02142-7, 2017.

Boyle, J. F., Plater, A. J., Mayers, C., Turner, S. D., Stroud, R. W., and Weber, J. E.: Land use, soil erosion, and sediment yield at Pinto Lake, California: Comparison of a simplified USLE model with the lake sediment record, J. Paleolimnol., 45, 199-212, https://doi.org/10.1007/s10933-010-9491-8, 2011.

Bridges, E. and Oldeman, L.: Global Assessment of HumanInduced Soil Degradation, Arid Soil Res. Rehabil., 13, 319-325, https://doi.org/10.1080/089030699263212, 1999 (data available at: http://data.isric.org/geonetwork/ srv/eng/catalog.search \T1\textbackslash\#/metadata/

9e84c15e-cb46-45e2-9126-1ca38bd5cd22, last access: 23 November 2018).

Carroll, M. L., DiMiceli, C. M., Sohlberg, R. A., and Townshend, J. R. G.: $250 \mathrm{~m}$ MODIS Normalized Difference Vegetation Index, Collection 4, University of Maryland, College Park, Maryland, 2004 (data available at: http://glcf.umd.edu/data/ndvi/, last access: 23 November 2018).

Chen, L., Qian, X., and Shi, Y.: Critical Area Identification of Potential Soil Loss in a Typical Watershed of the Three Gorges Reservoir Region, Water. Resour. Manage., 25, 3445-3463, https://doi.org/10.1007/s11269-011-9864-4, 2011.

Dabney, S. M., Yoder, D. C., and Vieira, D. A. N.: The application of the Revised Universal Soil Loss Equation, Version 2, to evaluate the impacts of alternative climate change scenarios on runoff and sediment yield, J. Soil Water Conserv., 67, 343-353, https://doi.org/10.2489/jswc.67.5.343, 2012.

da Silva, A. M.: Rainfall erosivity map for Brazil, Catena, 57, 251259, https://doi.org/10.1016/j.catena.2003.11.006, 2004.

David, W. P.: Soil and Water Conservation Planning: Policy Issues and Recommendations, J. Philipp. Dev., 15, 47-84, 1988.

de Asis, A. M. and Omasa, K.: Estimation of vegetation parameter for modeling soil erosion using linear Spectral Mixture Analysis of Landsat ETM data, ISPRS J. Photogramm. Remote. Sens., 62, 309-324, https://doi.org/10.1016/j.isprsjprs.2007.05.013, 2007. 
de Mello, C. R., Norton, L. D., Pinto, L. C., Beskow, S., and Curi, N.: Agricultural watershed modeling: a review for hydrology and soil erosion processes, Ciencia E Agrotecnologia, 40, 7-25, https://doi.org/10.1590/S1413-70542016000100001, 2016.

de Vente, J. and Poesen, J.: Predicting soil erosion and sediment yield at the basin scale: Scale issues and semi-quantitative models, Earth Sci. Rev., 71, 95-125, https://doi.org/10.1016/j.earscirev.2005.02.002, 2005.

Delgado, M. E. M. and Canters, F:. Modeling the impacts of agroforestry systems on the spatial patterns of soil erosion risk in three catchments of Claveria, the Philippines, Agroforestry Syst., 85, 411-423, https://doi.org/10.1007/s10457-011-9442-z, 2012.

Demirci, A. and Karaburun, A.: Estimation of soil erosion using RUSLE in a GIS framework: A case study in the Buyukcekmece Lake watershed, northwest Turkey, Environ. Earth. Sci., 66, 903913, https://doi.org/10.1007/s12665-011-1300-9, 2012.

Desmet, P. J. J. and Govers, G.: A GIS procedure for automatically calculating the USLE LS factor on topographically complex landscape units, J. Soil Water Conserv., 51, 427-433, 1996.

Diodato, N.: Estimating RUSLE's rainfall factor in the part of Italy with a Mediterranean rainfall regime, Hydrol. Earth Syst. Sci., 8, 103-107, https://doi.org/10.5194/hess-8-103-2004, 2004.

Duarte, L., Teodoro, A., Gonçalves, J., Soares, D., and Cunha, M.: Assessing soil erosion risk using RUSLE through a GIS open source desktop and web application, Environ. Monit. Assess., 188, 1-16, https://doi.org/10.1007/s10661-016-5349-5, 2016.

Dumas, P. and Fossey, M.: Mapping potential soil erosion in the Pacific Islands: A case study of Efate Island (Vanuatu), 11th Pacific Science Inter-Congress: Pacific Countries and Their Ocean, Facing Local and Global Changes, 2009.

Durigon, V. L., Carvalho, D. F., Antunes, M. A. H., Oliveira, P. T. S., and Fernandes, M. M.: NDVI time series for monitoring RUSLE cover management factor in a tropical watershed, Int. J. Remote Sens., 35, 441-453, https://doi.org/10.1080/01431161.2013.871081, 2014.

Dymond, J. R.: Soil erosion in New Zealand is a net sink of $\mathrm{CO}_{2}$, Earth Surf. Proc. Land., 35, 1763-1772, https://doi.org/10.1002/esp.2014, 2010.

Eiumnoh, A.: Integration of Geographic Information Systems (GIS) and Satellite Remote Sensing (SRS) for Watershed Management, Technical Bulletin 150, 2000.

El-Swaify, S. A., Gramier, C. L., and Lo, A.: Recent advances in soil conservation in steepland in humid tropics, in: Proceedings of the International Conference on Steepland Agriculture in the Humid Tropics, 87-100, Kuala Lumpur, MADI, 1987.

El-Swaify, S. A. and Dangler, E. W: Erodibilities of selected tropical soils in relation to structural and hydrologic parameters, Soil Conserv. Soc. Am., Ankeny, Iowa, 1976.

Eltaif, N., Gharaibeh, M., Al-Zaitawi, F., and Alhamad, M.: Approximation of rainfall erosivity factors in north Jordan, Pedosphere, 20, 711-717, https://doi.org/10.1016/S10020160(10)60061-6, 2010.

Farhan, Y. and Nawaiseh, S.: Spatial assessment of soil erosion risk using RUSLE and GIS techniques, Environ. Earth. Sci., 74, 4649-4669, https://doi.org/10.1007/s12665-015-4430-7, 2015.

Fernandez, C., Wu, J., McCool, D., and Stoeckle, C.: Estimating water erosion and sediment yield with GIS, RUSLE, and SEDD, J. Soil Water Conserv., 58, 128-136, 2003.
Fernandez, M. A. and Daigneault, A.: Erosion mitigation in the Waikato District, New Zealand: economic implications for agriculture, Int. J. Food Agric. Econ., 48, 1-21, https://doi.org/10.1111/agec.12338, 2016.

Ferreira, V. and Panagopoulos, T.: Seasonality of soil erosion under Mediterranean conditions at the Alqueva dam watershed, Environ. Manage., 54, 67-83, https://doi.org/10.1007/s00267-0140281-3, 2014.

Ferro, V., Giordano, G., and Iovino, M.: Isoerosivity and erosion risk map for Sicily, Hydrol. Sci. J., 36, 549-564, https://doi.org/10.1080/02626669109492543, 1991.

Flabouris, K.: Study of rainfall factor R on the RUSLE law, (Doctoral dissertation), Aristotle University of Thessaloniki, Greece, 2008.

Foster, G. R., Toy, T. E., and Renard, K. G.: Comparison of the USLE, RUSLE1.06c, and RUSLE2 for Application to Highly Disturbed Lands, in: First Interagency Conference on Research in Watersheds, 27-30 October, 154-160, United States Department of Agriculture, 2003.

Fu, G., Chen, S., and McCool, D.: Modeling the Impacts of no-till practice on Soil Erosion and Sediment Yield with RUSLE, SEDD, and ArcView GIS, Soil Till. Res., 85, 38-49, https://doi.org/10.1016/j.still.2004.11.009, 2006.

Gaubi, I., Chaabani, A., Ben Mammou, A., and Hamza, M. H.: A GIS-based soil erosion prediction using the Revised Universal Soil Loss Equation (RUSLE) (Lebna watershed, Cap Bon, Tunisia), Nat. Hazards, 86, 219-239, https://doi.org/10.1007/s11069-016-2684-3, 2017.

Hernandez, E. C., Henderson, A., and Oliver, D. P.: Effects of changing land use in the Pagsanjan-Lumban catchment on suspended sediment loads to Laguna de Bay, Philippines, Agric. Water Manag., 106, 8-16, https://doi.org/10.1016/j.agwat.2011.08.012, 2012.

Hudson, N. W.: Soil Conservation, Ithaca, New York, Cornell University Press, 1971.

Institute of Water Research: RUSLE - An online soil erosion assessment tool, available at: http://www.iwr.msu.edu/rusle/ (last access: 19 November 2018), 2015.

İrvem, A., Topaloğlu, F., and Uygur, V.: Estimating spatial distribution of soil loss over Seyhan River Basin in Turkey, J. Hydrol. 336, 30-37, https://doi.org/10.1016/j.jhydrol.2006.12.009, 2007.

Jahun, B. G., Ibrahim, R., Dlamini, N. S., and Musa, S. M.: Review of Soil Erosion Assessment using RUSLE Model and GIS, J. Biol. Agric. Healthc., 5, 36-47, 2015.

Jain, M. K. and Das, D.: Estimation of sediment yield and areas of soil erosion and deposition for watershed prioritization using GIS and remote sensing, Water Resour. Manage., 24, 2091-2112, https://doi.org/10.1007/s11269-009-9540-0, 2010.

Jayasinghe, P. K. S. C., Adornado, H. A., Yoshida, M., and Leelamanie, D. A. L.: A Web-Based GIS and Remote Sensing Framework for Spatial Information System (SIS): A Case Study in Nuwaraeliya, Sri Lanka, Agricultural Information Research, 19, 106-116, https://doi.org/10.3173/air.19.106, 2010.

Kavian, A., Fathollah Nejad, Y., Habibnejad, M., and Soleimani, K.: Modeling seasonal rainfall erosivity on a regional scale: A case study from Northeastern Iran, Int. J. Environ. Res., 5, 939-950, 2011.

Kim, J. B., Saunders, P., and Finn, J. T.: Rapid assessment of soil erosion in the Rio Lempa Basin, Central America, using the uni- 
versal soil loss equation and geographic information systems, Environ. Manage., 36, 872-885, https://doi.org/10.1007/s00267002-0065-z, 2005.

Kinnell, P. I. A.: Event soil loss, runoff and the Universal Soil Loss Equation family of models: A review, J. Hydrol., 385, 384-397, https://doi.org/10.1016/j.jhydrol.2010.01.024, 2010.

Klik, A., Haas, K., Dvorackova, A., and Fuller, I. C.: Spatial and temporal distribution of rainfall erosivity in New Zealand, Soil Res., 53, 815-825, 2015.

Kulikov, M., Schickhoff, U., and Borchardt, P.: Spatial and seasonal dynamics of soil loss ratio in mountain rangelands of south-western Kyrgyzstan, J. Mt. Sci., 13, 316-329, https://doi.org/10.1007/S11629-014-3393-6, 2016.

Land Development Department: Assessment of Soil Loss using the Equation of Soil Loss, Bangkok, Thailand, 2002.

Le Roux, J., Morgenthal, T., Malherbe, J., Pretorius, D., and Sumner, P.: Water erosion prediction at a national scale for South Africa, Water SA, 34, available at: http://www.scielo.org.za/ scielo.php?script=sci_arttext\&pid=S1816-79502008000300003 (last access: 19 November 2018), 2005.

Li, L., Wang, Y., and Liu, C.: Effects of land use changes on soil erosion in a fast developing area, Int. J. Environ. Sci. Technol., 11, 1549-1562, https://doi.org/10.1007/s13762-013-0341-x, 2014.

López-Vicente, M., Navas, A., and Machín, J.: Identifying erosive periods by using RUSLE factors in mountain fields of the Central Spanish Pyrenees, Hydrol. Earth Syst. Sci., 12, 523-535, https://doi.org/10.5194/hess-12-523-2008, 2008.

Loureiro, N. D. S. and Coutinho, M. D. A.: A new procedure to estimate the RUSLE EI30 index, based on monthly rainfall data and applied to the Algarve region, Portugal, J. Hydrol., 250, 1218, https://doi.org/10.1016/S0022-1694(01)00387-0, 2001.

Lu, H., Prosser, I. P., Moran, C. J., Gallant, J. C., Priestley, G., and Stevenson, J. G.: Predicting sheetwash and rill erosion over the Australian continent, Soil Res., 41, 1037-1062, https://doi.org/10.1071/SR02157, 2003

$\mathrm{Lu}, \mathrm{H}$. and $\mathrm{Yu}, \quad \mathrm{B}$. S Spatial and seasonal distribution of rainfall erosivity in Australia, Soil Res., 40, 887, https://doi.org/10.1071/SR01117, 2002.

Ma, H. L., Wang, Z. L., and Zhou, X.: Estimation of soil loss based on RUSLE in Zengcheng, Guangdong Province, Yangtze River, 41, 90-93, 2010.

Madarcos, B. S.: Soil Erosion in Four Cashew-based Crops Under Two Slope Categories, University of the Philippines at Los Baños Library, 1985.

Merritt, W. S., Letcher, R. A., and Jakeman, A. J.: A review of erosion and sediment transport models, Environ. Model Softw., 18, 761-799, https://doi.org/10.1016/S1364-8152(03)00078-1, 2003.

Merritt, W. S., Croke, B. F. W., Jakeman, A. J., Letcher, R. A., and Perez, P.: A Biophysical Toolbox for assessment and management of land and water resources in rural catchments in Northern Thailand, Ecol. Modell., 171, 279-300, https://doi.org/10.1016/j.ecolmodel.2003.08.010, 2004.

Merzouk, A.: Relative erodibility of nine selected Moroccan soils as related to their physical, chemical, and mineralogical properties, (Doctoral dissertation), University of Minnesota, St. Paul, United States of America, 1985.
Mihara, H.: Raindrop and Soil Erosion, National Institute of Agricultural Science Bulletin Series A, 1, 1-59, National Institute of Agricultural Science, Tokyo, 1951.

Mitasova, H., Hofierka, J., Zlocha, M., and Iverson, L.: Modelling topographic potential for erosion and deposition using GIS, Int. J. Geogr. Inf. Sci., 10, 629-641, https://doi.org/10.1080/02693799608902101, 1996.

Mitasova, H., Barton, M., Ullah, I., Hofierka, J., and Harmon, R.: GIS-Based Soil Erosion Modeling, in: Treatise on Geomorphology, 3, 228-258, Academic Press, San Diego, Califronia, https://doi.org/10.1016/B978-0-12-374739-6.00052-X, 2013.

Momm, H. G., Bingner, R. L., Wells, R. R., and Wilcox, D.: Agnps GIS-based tool for watershed-scale identification and mapping of cropland potential ephemeral gullies, Appl. Eng. Agric., 28, 17-29, 2012.

Moore, I. D. and Burch, G. J.: Physical basis of the length-slope factor in the Universal Soil Loss Equation, Soil Sci. Soc. Am. J., 50, 1294-1298, 1986.

Moore, I. D., Grayson, R. B., and Ladson, A. R.: Digital Terrain Modeling?: A Review of Hydrological Geomorphological and Biological Applications, Hydrol. Process., 5, 3-30, https://doi.org/10.1002/hyp.3360050103, 1991.

Morgan, R. P. C.: Estimating regional variations in soil erosion hazard in Peninsular Malaysia, Malayan Nature Journal, 28, 94-106, 1974.

Morgan, R. P. C.: Soil Erosion and Conservation, Longman Group Ltd., Essex, 1986.

Morgan, R. P. C.: Soil Erosion and Conservation, National Soil Resources Institute, Cranfield University, https://doi.org/10.1002/9781118351475.ch22, 2005.

Nagle, G. N., Fahey, T. J., and Lassoie, J. P.: Management of sedimentation in tropical watersheds, Environ. Manage., 23, 441452, https://doi.org/10.1007/s002679900199, 1999.

Naipal, V., Reick, C., Pongratz, J., and Van Oost, K.: Improving the global applicability of the RUSLE model - adjustment of the topographical and rainfall erosivity factors, Geosci. Model Dev., 8, 2893-2913, https://doi.org/10.5194/gmd-8-2893-2015, 2015.

Nakil, M.: Analysis of parameters causing water induced soil erosion, Unpublished Fifth Annual Progress Seminar, Indian Institute of Technology, Bombay, 2014.

Nakil, M. and Khire, M.: Effect of slope steepness parameter computations on soil loss estimation: review of methods using GIS, Geocarto Int., 31, 1078-1093, https://doi.org/10.1080/10106049.2015.1120349, 2016.

NASA: Normalized Difference Vegetation Index, New York City, USA, NASA Goddard Institute for Space Studies, available at: https://data.giss.nasa.gov/landuse/ndvi.html, last access: 23 November 2018.

Nigel, R. and Rughooputh, S. D. D. V.: Application of a RUSLEbased soil erosion modelling on Mauritius Island, Soil Res., 50, 645-651, 2012.

Nontananandh, S. and Changnoi, B.: Internet GIS, based on USLE modeling, for assessment of soil erosion in Songkhram watershed, Northeastern of Thailand, Kasetsart Journal - Natural Science, 46, 272-282, 2012.

Ochoa-Cueva, P., Fries, A., Montesinos, P., Rodríguez-Díaz, J. A., and Boll, J.: Spatial Estimation of Soil Erosion Risk by Landcover Change in the Andes of Southern Ecuador, Land Degrad. Dev., 26, 565-573, https://doi.org/10.1002/ldr.2219, 2015. 
Ozsoy, G., Aksoy, E., Dirim, M. S., and Tumsavas, Z.: Determination of soil erosion risk in the mustafakemalpasa river basin, Turkey, using the revised universal soil loss equation, geographic information system, and remote sensing, Environ. Manage., 50, 679-694, https://doi.org/10.1007/s00267-012-9904-8, 2012.

Panagos, P., Karydas, C. G., Gitas, I. Z., and Montanarella, L.: Monthly soil erosion monitoring based on remotely sensed biophysical parameters: a case study in Strymonas river basin towards a functional pan-European service, Int. J. Digit. Earth, 5, 461-487, https://doi.org/10.1080/17538947.2011.587897, 2012.

Panagos, P., Meusburger, K., Ballabio, C., Borrelli, P., and Alewell, C.: Soil erodibility in Europe: A high-resolution dataset based on LUCAS, Sci. Total Environ., 479-480, 189-200, https://doi.org/10.1016/j.scitotenv.2014.02.010, 2014.

Panagos, P., Borrelli, P., and Meusburger, K.: A New European Slope Length and Steepness Factor (LS-Factor) for Modeling Soil Erosion by Water, Geosciences, 5, 117-126, https://doi.org/10.3390/geosciences5020117, 2015a.

Panagos, P., Borrelli, P., Meusburger, K., Alewell, C., Lugato, E., and Montanarella, L.: Estimating the soil erosion covermanagement factor at the European scale, Land Use Policy, 48, 38-50, https://doi.org/10.1016/j.landusepol.2015.05.021, 2015b.

Panagos, P., Borrelli, P., Meusburger, K., Van Der Zanden, E. H., Poesen, J., and Alewell, C.: Modelling the effect of support practices ( $P$-factor) on the reduction of soil erosion by water at European scale, Environ. Sci. Policy, 51, 23-34, https://doi.org/10.1016/j.envsci.2015.03.012, 2015c.

Panagos, P., Ballabio, C., Borrelli, P., Meusburger, K., Klik, A., Rousseva, S., and Alewell, C.: Rainfall erosivity in Europe, Sci. Total Environ., 511, 801-814, https://doi.org/10.1016/j.scitotenv.2015.01.008, 2015d (data available at: https://esdac.jrc.ec.europa.eu/content/ rainfall-erosivity-european-union-and-switzerland, last access: 23 November 2018).

Panagos, P., Borrelli, P., Poesen, J., Ballabio, C., Lugato, E., Meusburger, K., and Alewell, C.: The new assessment of soil loss by water erosion in Europe, Environ. Sci. Policy, 54, 438-447, https://doi.org/10.1016/j.envsci.2015.08.012, 2015e.

Panagos, P., Borrelli, P., Meusburger, K., Yu, B., Klik, A., Jae Lim, K., and Ballabio, C.: Global rainfall erosivity assessment based on high-temporal resolution rainfall records, Sci. Rep., 7, 4175, https://doi.org/10.1038/s41598-017-042828, 2017 (data available at: https://esdac.jrc.ec.europa.eu/content/ global-rainfall-erosivity, last access: 23 November 2018).

Pimentel, D., Harvey, C., Resosudarmo, P., Sinclair, K., Kurz, D., McNair, M., and Blair, R.: Environmental and Economic Costs of Soil Erosion and Conservation Benefits, Science, 267, 11171123, https://doi.org/10.1126/science.267.5201.1117, 1995.

Post, D. A. and Hartcher, M. G.: Evaluating uncertainty in modelled sediment delivery in data-sparse environments: application to the Mae Chaem Catchment, Thailand, in: Proceedings of symposium S7 held during the Seventh IAHS Scientific Assembly, 80-89, Foz do Iguaçu, 2005.

Raissouni, A., Issa, L., Lech-Hab, K., and El Arrim, A.: Water Erosion Risk Mapping and Materials Transfer in the Smir Dam Watershed (Northwestern Morocco), JGEESI, 5, 1-17, https://doi.org/10.9734/JGEESI/2016/20061, 2016.
Ram, B., Dhyani, B. L., and Kumar, N.: Assessment of erodibility status and refined Iso-Erodent Map of India, Indian Journal of Soil Conservation, 32, 171-177, 2004.

Rango, A. and Arnoldus, H.: Aménagement des bassins versants, Cahiers techniques de la FAO, Food and Agriculture Organization of the United Nations, 1987.

Renard, K. and Freimund, J. R.: Using monthy precipitation data to estimate $R$-factor in the revised USLE, J. Hydrol., 157, 287-306, 1994.

Renard, K., Foster, G., Weesies, G., McCool, D., and Yoder, D.: Predicting soil erosion by water: a guide to conservation planning with the Revised Universal Soil Loss Equation (RUSLE), Agricultural Handbook No. 703, 65-100, https://doi.org/10.1201/9780203739358-5, 1997.

Rodda, H. J. E., Stroud, M. J., Shankar, U., and Thorrold, B. S.: A GIS based approach to modelling the effects of land-use change on soil erosion in New Zealand, Soil Use Manag., 17, 30-40, https://doi.org/10.1111/j.1475-2743.2001.tb00005.x, 2001.

Roose, E. J.: Erosion et ruissellement en Afrique de l'ouest: vingt années de mesures en petites parcelles expérimentales, Adiopodoumé, Ivory Coast, 1975.

Rosewell, C.: Potential Sources of Sediments and Nutrients: Sheet and Rill Erosion and Phosphorous Sources, in: State of the Environment Technical Paper Series (Inland Waters), Department of the Environment, Sport and Territories, Canberra, Australia, 1997.

Rosewell, C. and Turner, J.: Rainfall Erosivity in New South Wales, Issue 20 of Technical Report, Department of Conservation and Land Management, Sydney, 1992.

Roslee, R., Bidin, K., Musta, B., Tahir, S., Tongkul, F., and Norhisham, M. N.: GIS Application for Comprehensive Spatial Soil Erosion Analysis with MUSLE Model in Sandakan Town Area, Sabah, Malaysia, Geological Behavior, 1, 1-5, 2017.

Rozos, D., Skilodimou, H. D., Loupasakis, C., and Bathrellos, G. D.: Application of the revised universal soil loss equation model on landslide prevention. An example from N. Euboea (Evia) Island, Greece, Environ. Earth. Sci., 70, 3255-3266, https://doi.org/10.1007/s12665-013-2390-3, 2013.

Russo, A:. Applying the Revised Universal Soil Loss Equation model to land use planning for erosion risk in Brunei Darussalam, Australian Planner, 3682, 1-17, https://doi.org/10.1080/07293682.2014.957332, 2015.

Sadeghi, S. H. R., Gholami, L., Khaledi Darvishan, A., and Saeidi, P.: A review of the application of the MUSLE model worldwide, Hydrolog. Sci. J., 59, 365-375, https://doi.org/10.1080/02626667.2013.866239, 2014.

Sadeghifard, D., Jabari, E., and Ghayasian, H.: Rainfall erosivity zonation in Iran, in: The First National Conference on Civil Engineering, Sharif University of Technology, Iran, available at: https://www.civilica.com/Paper-NCCE01-226_2417394703. html (last access: 19 November 2018), 2004.

Schmitt, L. K.: Developing and applying a soil erosion model in a data-poor context to an island in the rural Philippines, Environ. Dev. Sustain., 11, 19-42, https://doi.org/10.1007/s10668007-9096-1, 2009.

Shamshad, A., Azhari, M. N., Isa, M. H., Hussin, W. M. A. W., and Parida, B. P.: Development of an appropriate procedure for estimation of RUSLE EI30 index and preparation of erosivity 
maps for Pulau Penang in Peninsular Malaysia, Catena, 72, 423432, https://doi.org/10.1016/j.catena.2007.08.002, 2008.

Sholagberu, A. T., Ul Mustafa, M. R., Wan Yusof, K., and Ahmad, M. H.: Evaluation of rainfall-runoff erosivity factor for Cameron highlands, Pahang, Malaysia, J. Ecol. Eng., 17, 1-8, https://doi.org/10.12911/22998993/63338, 2016.

Sinha, D. and Joshi, V. U.: Application of universal soil loss equation (USLE) to recently reclaimed badlands along the Adula and Mahalungi Rivers, Pravara Basin, Maharashtra, J. Geol. Soc. India, 80, 341-350, https://doi.org/10.1007/s12594-012-0152-6, 2012.

Smith, D. D. and Whitt, D. M.: Estimating Soil Loss from Field Area of Clay Pan Soils, Soil Sci. Soc. Am. J., 12, 485-490, 1947.

Stewart, B., Woolhiser, D., Wischmeier, W., Caro, J., and Frere, M. H.: Control of water pollution from cropland, United States Department of Agriculture, United States, 1975.

Thorne, C. R., Zevenbergen, L. W., Grissinger, E. H., and Murphey, J. B.: Calculator programe and nomograph for on-site predictions of ephemeral gully erosion, United States Department of Agriculture Soil Conservation Service, United States, 1985.

Torri, D., Poesen, J., and Borselli, L.: Predictability and uncertainty of the soil erodibility factor using a global dataset, CATENA, 46, 1-22, https://doi.org/10.1016/S0341-8162(97)00036-2, 1997.

USDA-ARS (U.S. Department of Agriculture - Agricultural Research Service): Revised Universal Soil Loss Equation, available at: https://www.ars.usda.gov/southeast-area/oxford$\mathrm{ms} /$ national-sedimentation-laboratory/watershed-physicalprocesses-research/docs/revised-universal-soil-loss-equationrusle-welcome-to-rusle-1 (last access: 19 November 2018), 2002.

van der Knijff, J. M., Jones, R. J. A., and Montanarella, L.: Soil Erosion Risk Assessment in Europe, available at: https: //www.preventionweb.net/files/1581_ereurnew2.pdf (last access: 21 November 2018), 2000.

Williams, R. J. and Renard, K. G.: EPIC - a new method for assessing erosions effect on soil productivity, J. Soil Water Conserv., 38, 381-383, 1983.
Wilson, J. P. and Gallant, J. C.: Digital Terrain Analysis, edited by: Wilson, J. P. and Gallant, J. C., in: Terrain Analysis: Principles and Applications, 1-28, 2000.

Wischmeier, W. H. and Mannering, J. V.: Relation of Soil Properties to its Erodibility, Soil and Water Management and Conservation, 15, 131-137, https://doi.org/10.2136/sssaj1969.03615995003300010035x, 1969.

Wischmeier, W. H. and Smith, D. D.: Predicting rainfall erosion losses, Agriculture Handbook No. 537, 537, 285-291, https://doi.org/10.1029/TR039i002p00285, 1978.

Wu, S., Li, J., and Huang, G.: An evaluation of grid size uncertainty in empirical soil loss modeling with digital elevation models, Environ. Model. Assess., 10, 33-42, https://doi.org/10.1007/s10666-004-6595-4, 2005.

Yoon, K. S., Kim, C., and Woo, H.: Application of RUSLE for Erosion Estimation of Construction Sites in Coastal Catchments, J. Coastal Res., 2, 1696-1700, 2009.

Yang, X., Chapman, G. A., Gray, J. M., and Young, M. A.: Delineating soil landscape facets from digital elevation models using compound topographic index in a geopgraphic information system, Soil Res., 45, 569-576, 2007.

Zakerinejad, R. and Maerker, M.: An integrated assessment of soil erosion dynamics with special emphasis on gully erosion in the Mazayjan basin, southwestern Iran, Nat. Hazards, 79, 25-50, https://doi.org/10.1007/s11069-015-1700-3, 2015.

Zhou, F. J., Chen, M. H., Lin, F. X., Huang, Y. H., and Lu, C. L.: The rainfall erosivity index in Fujian Province, J. Soil Water Conserv., 9, 13-18, 1995.

Životić, L., Perović, V., Jaramaz, D., Dordević, A., Petrović, R., and Todorović, M.: Application of USLE, GIS, and remote sensing in the assessment of soil erosion rates in Southeastern Serbia, Pol. J. Environ. Stud., 21, 1929-1935, 2012. 